Supplementary Information

\title{
Development of Robust 17(R),18(S)-Epoxyeicosatetraenoic Acid (17,18-EEQ) Analogs as Potential Clinical Antiarrhythmic Agents
}

Adeniyi Michael Adebesin, ${ }^{\dagger}$ Tim Wesser, ${ }^{\#}$ Jonnalagadda Vijaykumar, ${ }^{\dagger}$ Anne Konkel, ${ }^{\#}$ Mahesh P. Paudyal,${ }^{\dagger}$ Janine Lossie,${ }^{\S}$ Chen Zhu,${ }^{\dagger}$ Christina Westphal,${ }^{\S}$ Narender Puli, ${ }^{\dagger}$ Robert Fischer, ${ }^{\S}$ Wolf-Hagen Schunck, ${ }^{*}$, and John R. Falck*,†

Division of Chemistry, Department of Biochemistry, University of Texas Southwestern, Dallas, TX 75390 USA. "OMEICOS Therapeutics GmbH, Robert Rössle Straße 10, 13125 Berlin, Germany. ${ }^{\S}$ Max Delbrück Center for Molecular Medicine, Robert-Rössle-Straße 10, 13125

Berlin, Germany

\section{CORRESPONDING AUTHORS}

*E-mail: Schunck@mdc-berlin.de. Phone: +49-30 94063750 (WHS)

*E-Mail: J.Falck@UTSouthwestern.edu. Phone: (214) 648-2406 (JRF)

\section{TABLE OF CONTENTS}

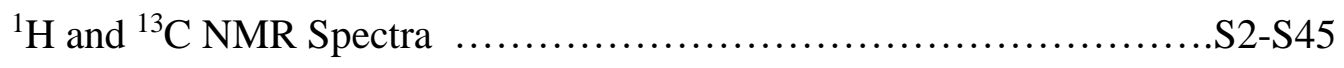



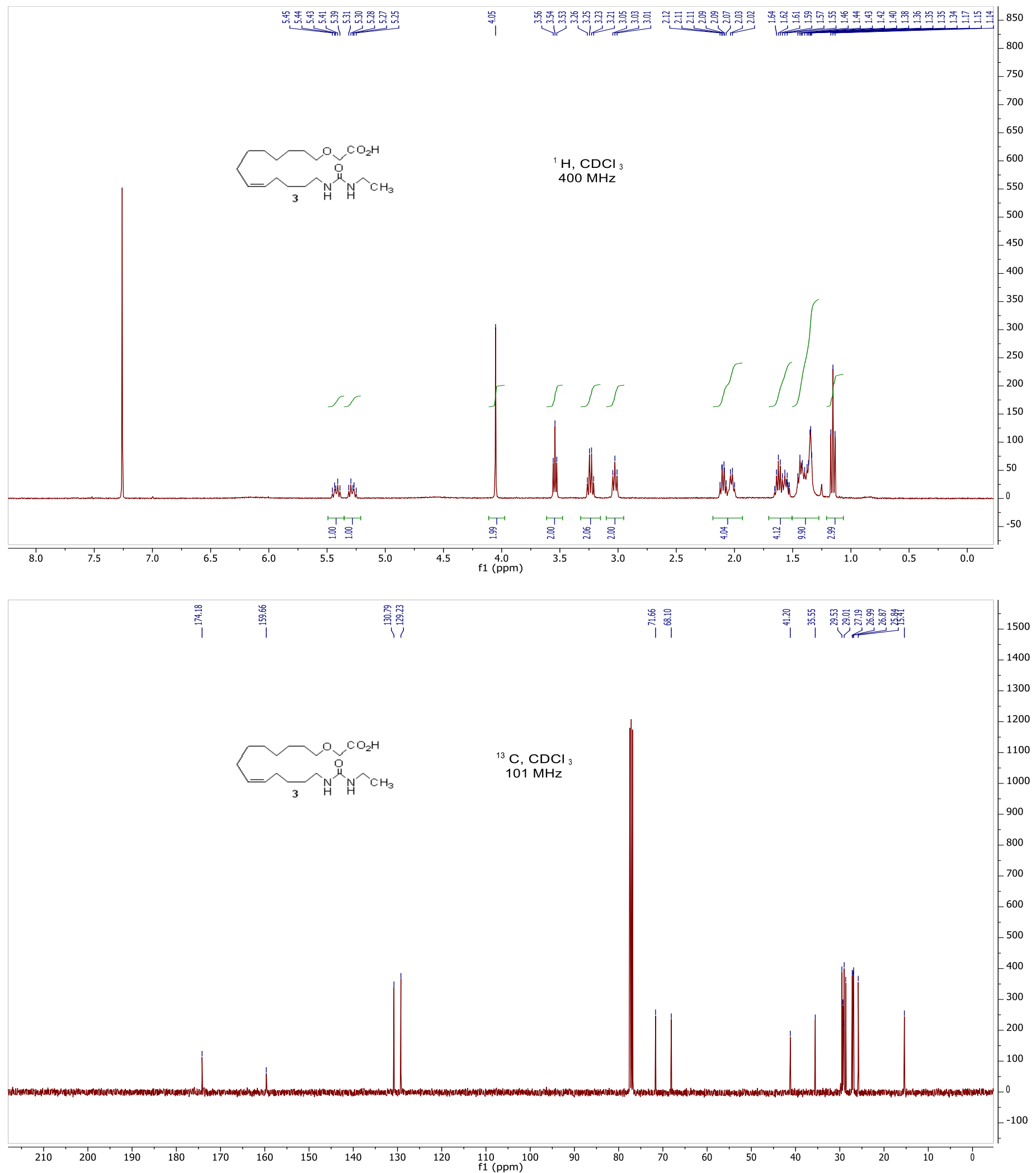

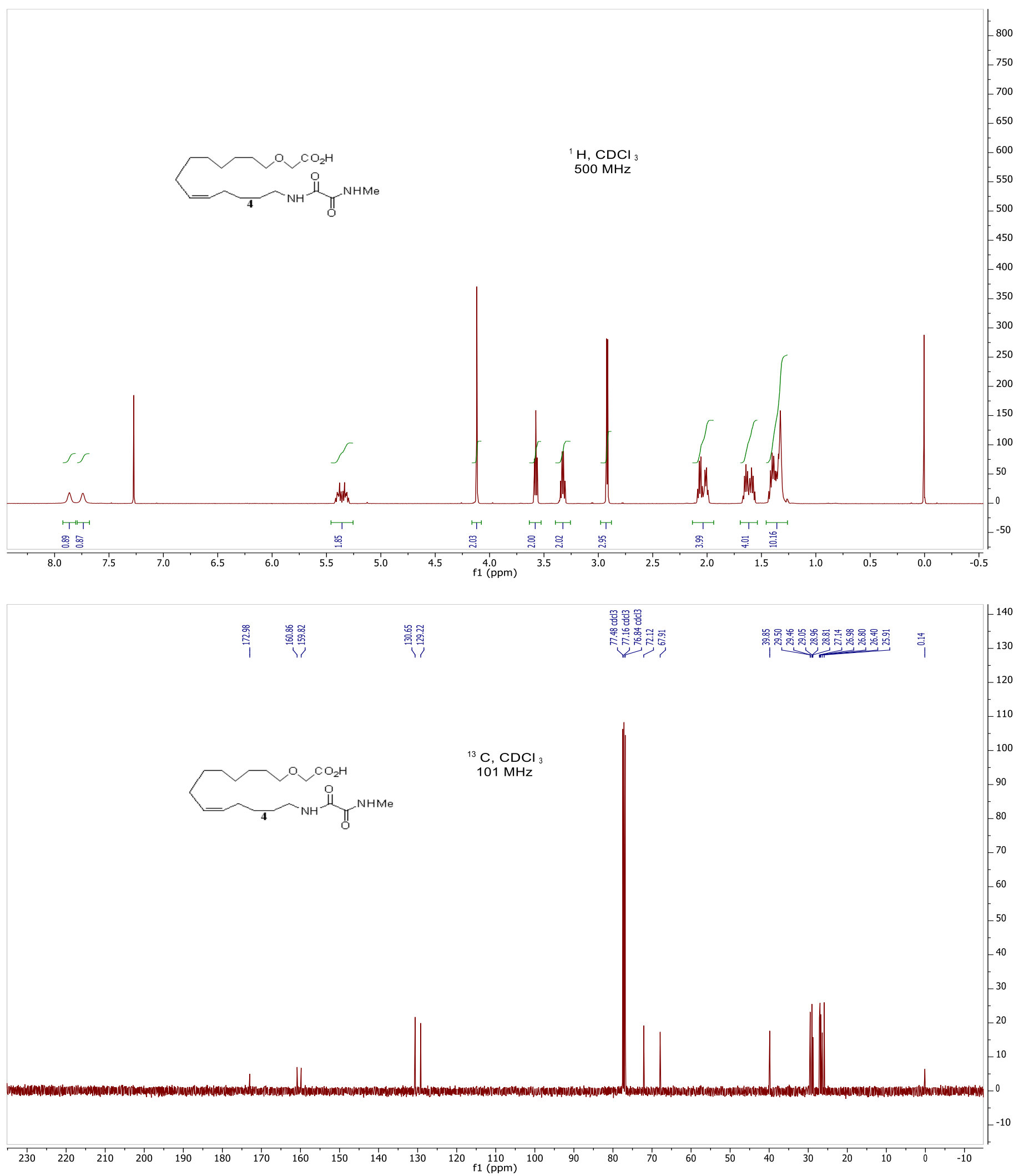


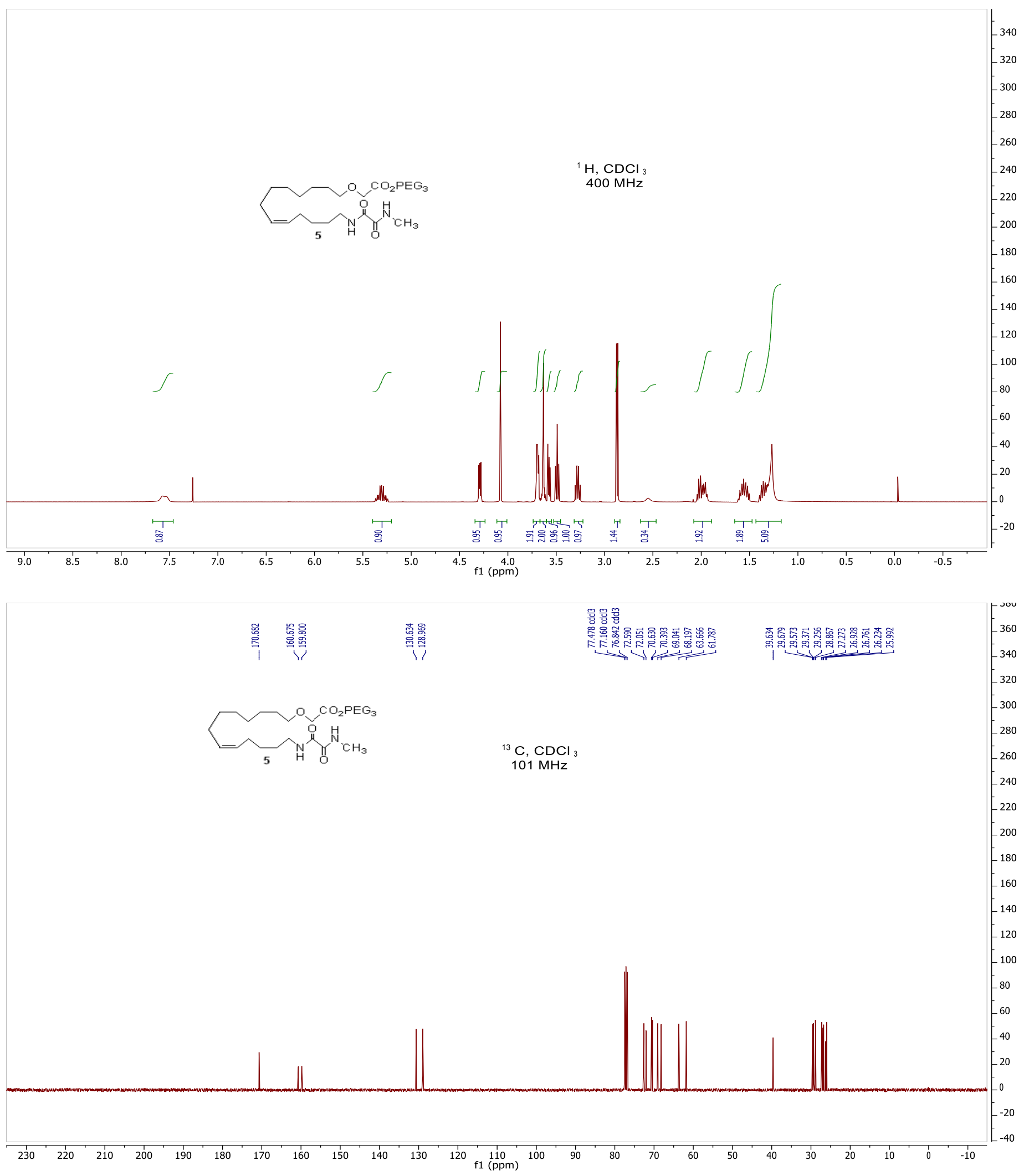



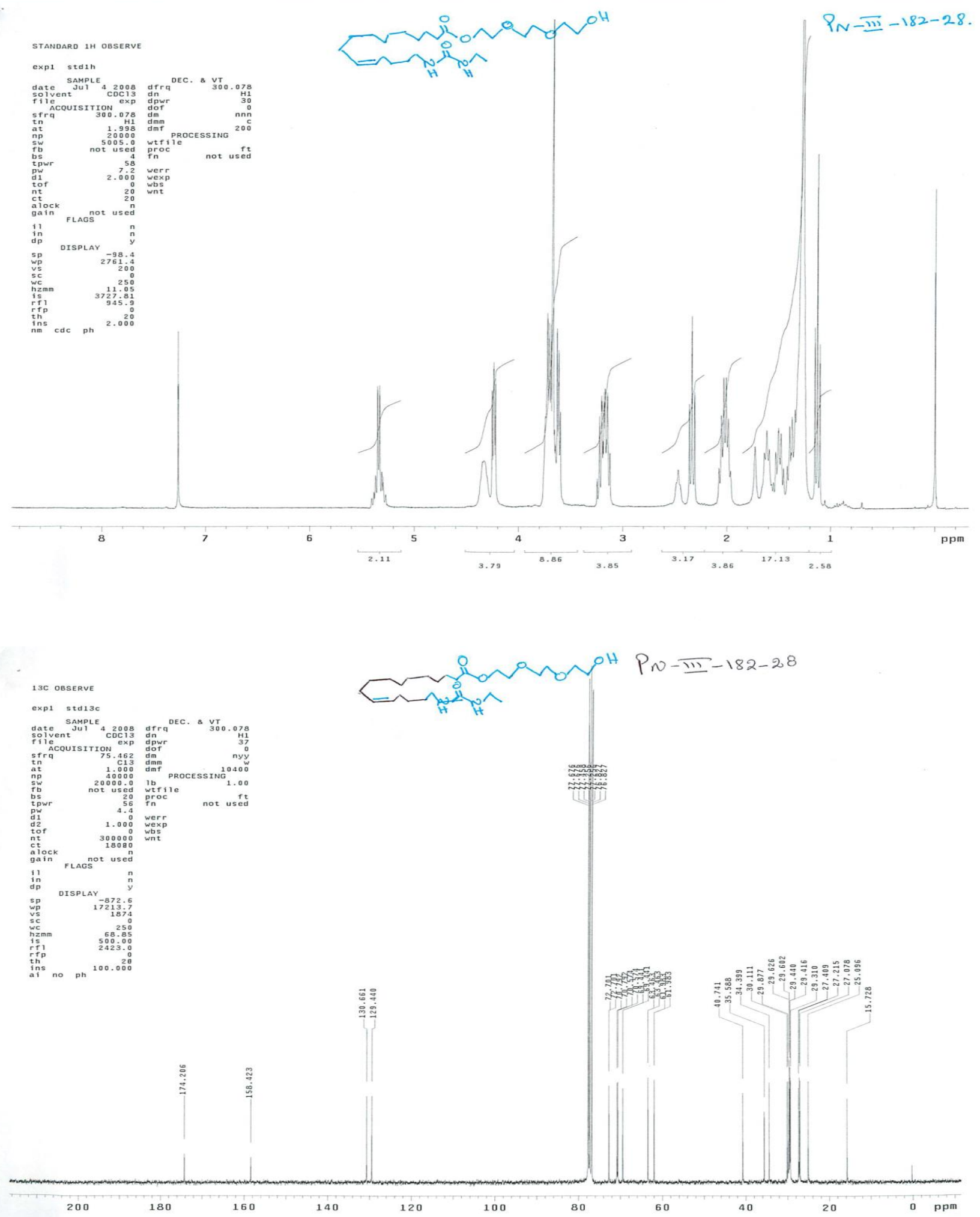

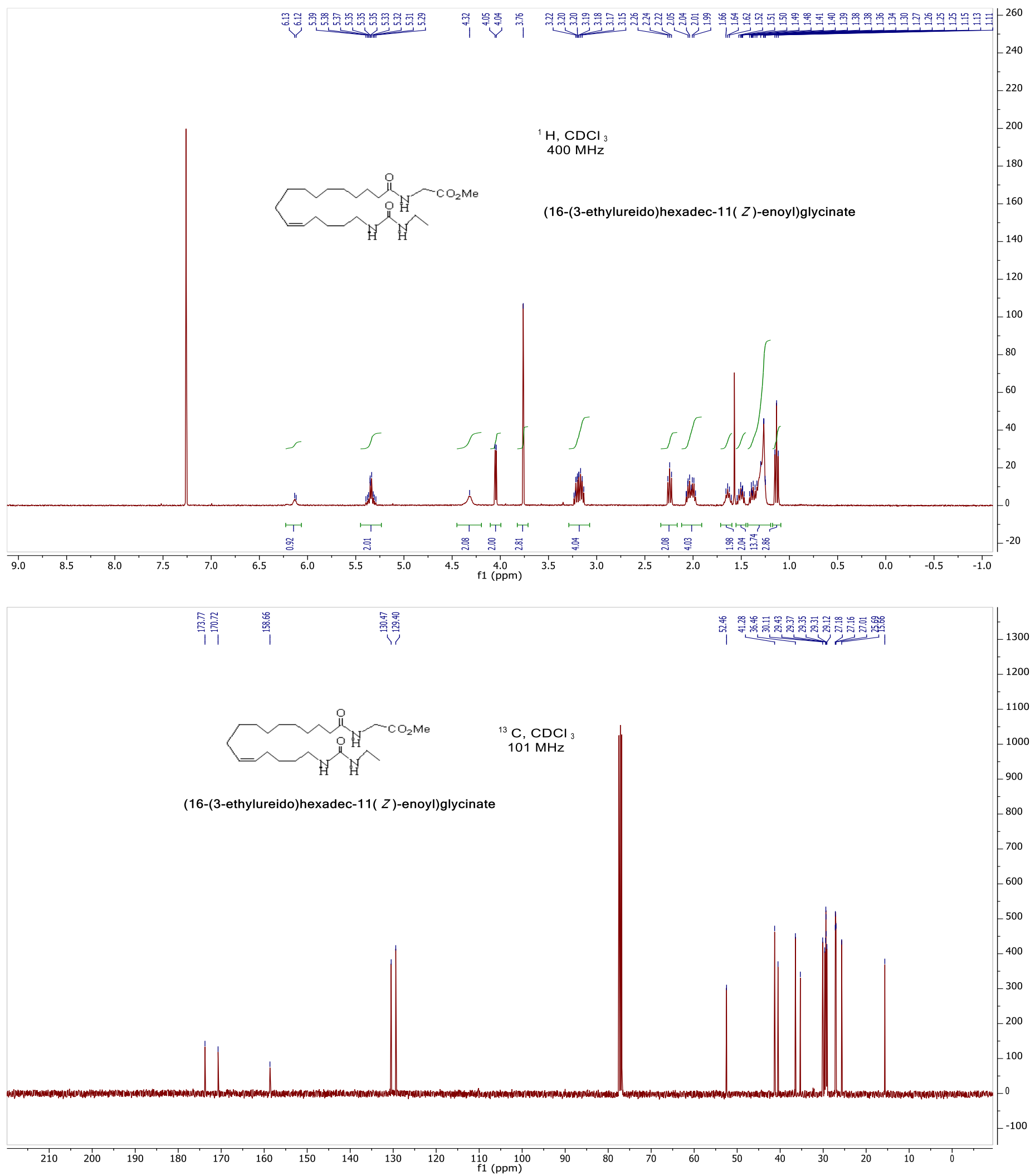

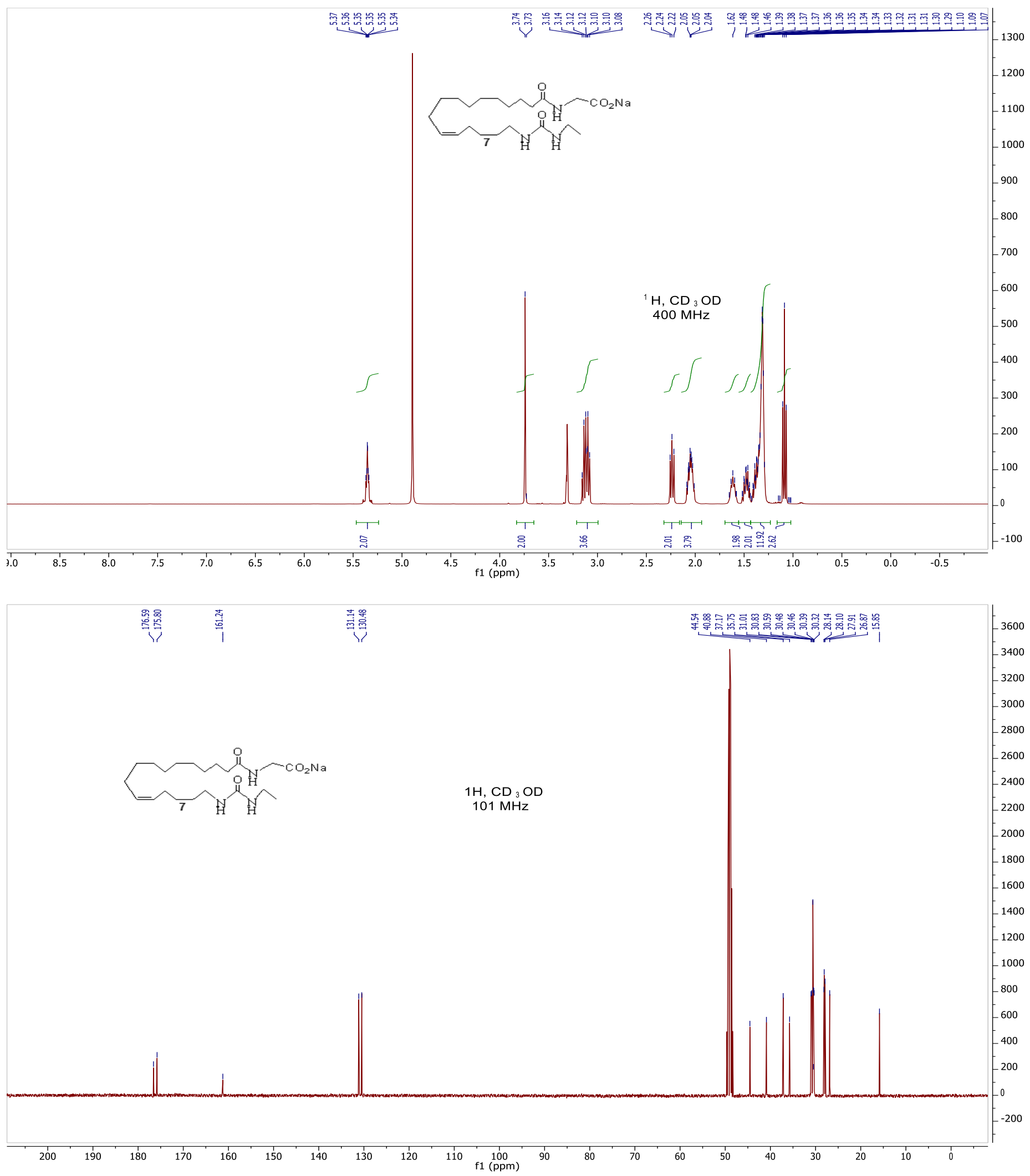


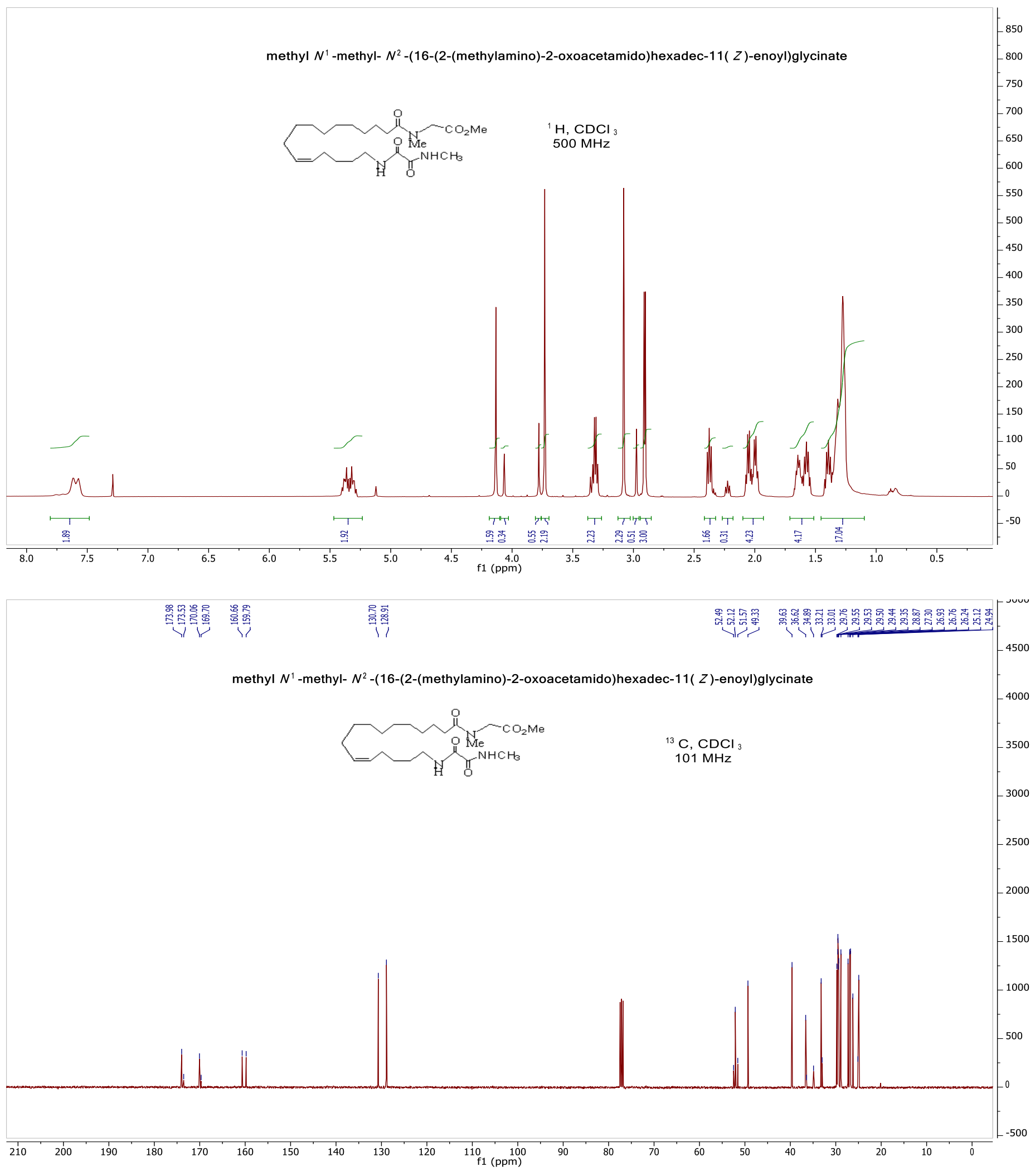




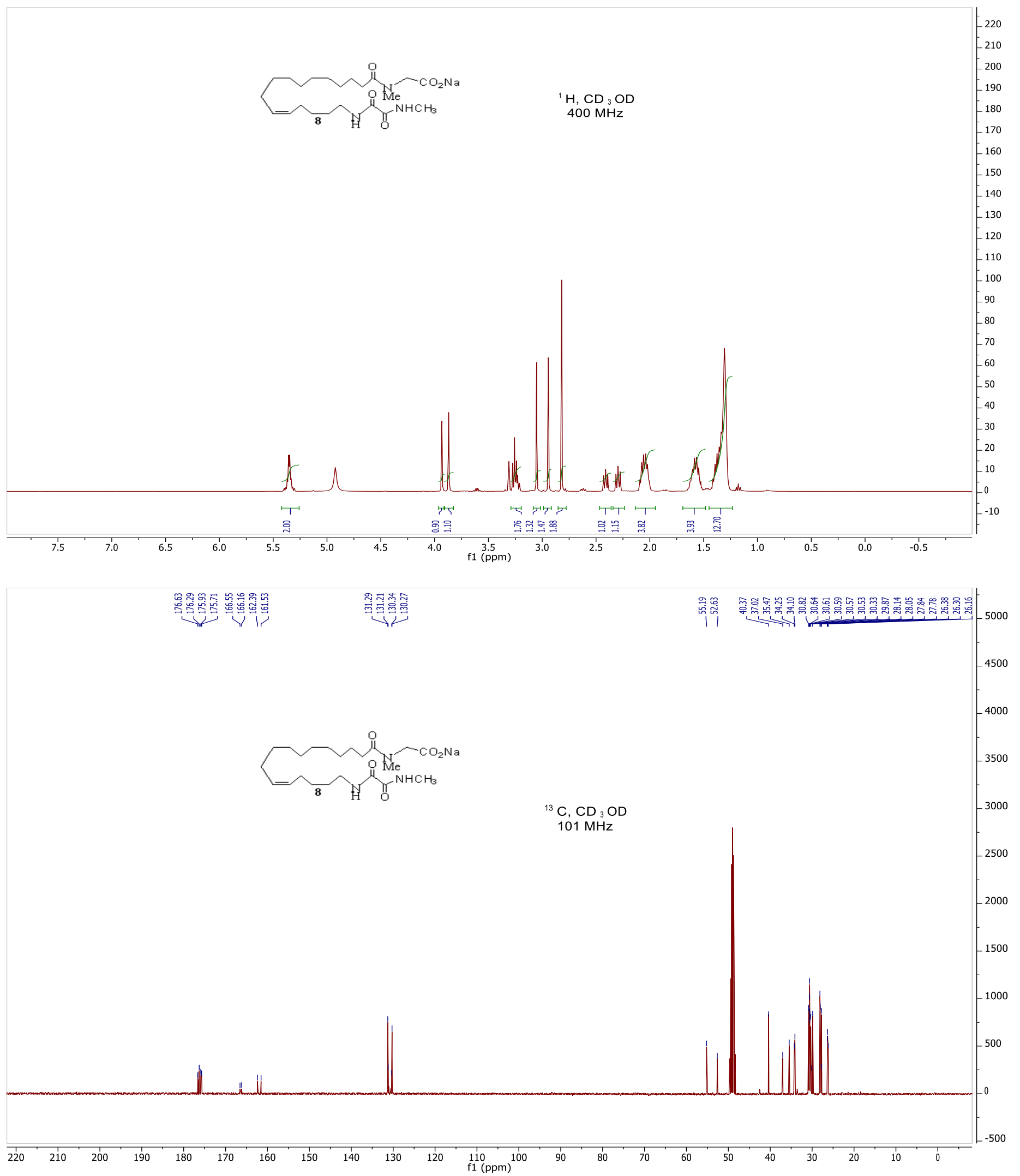




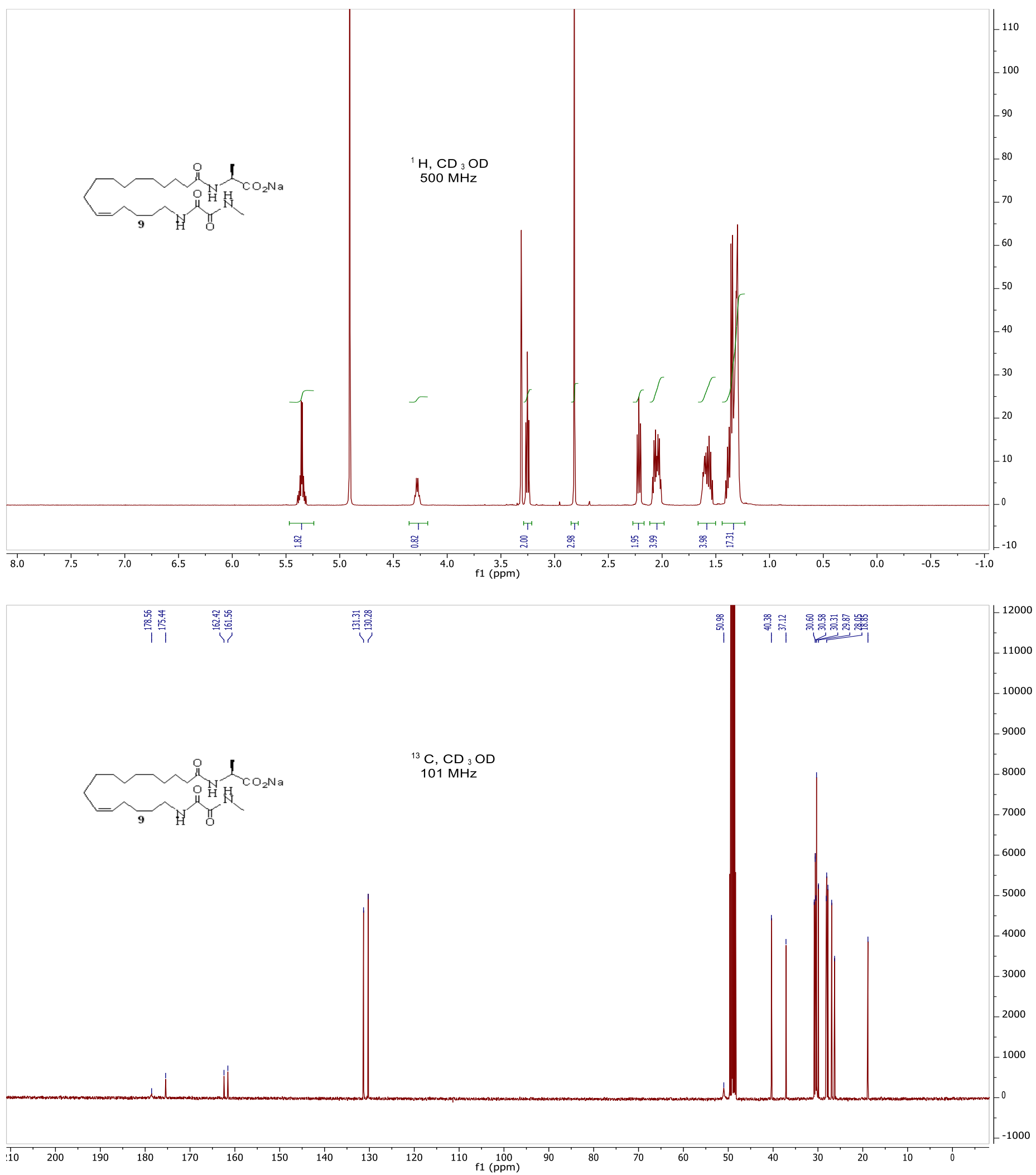




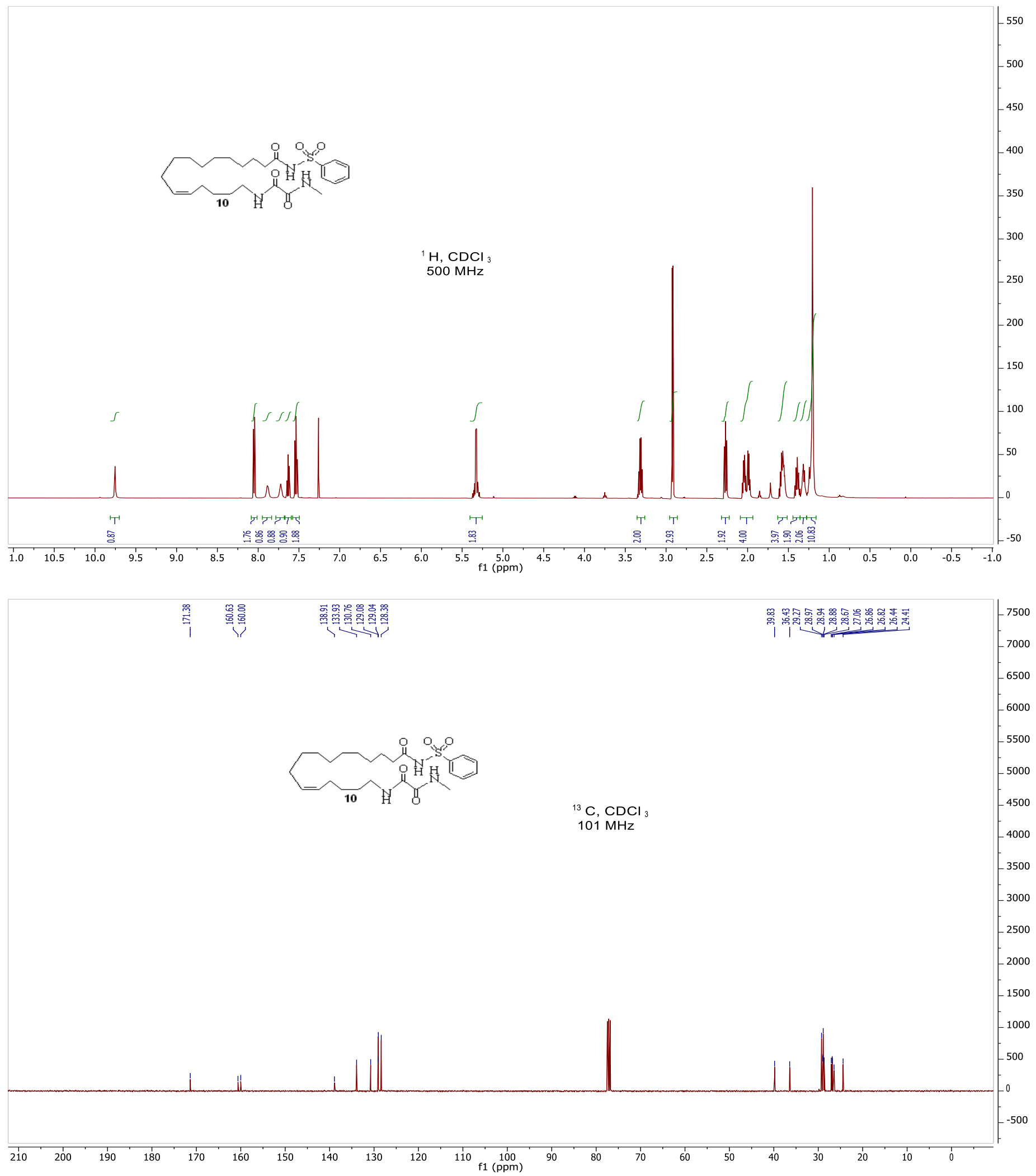




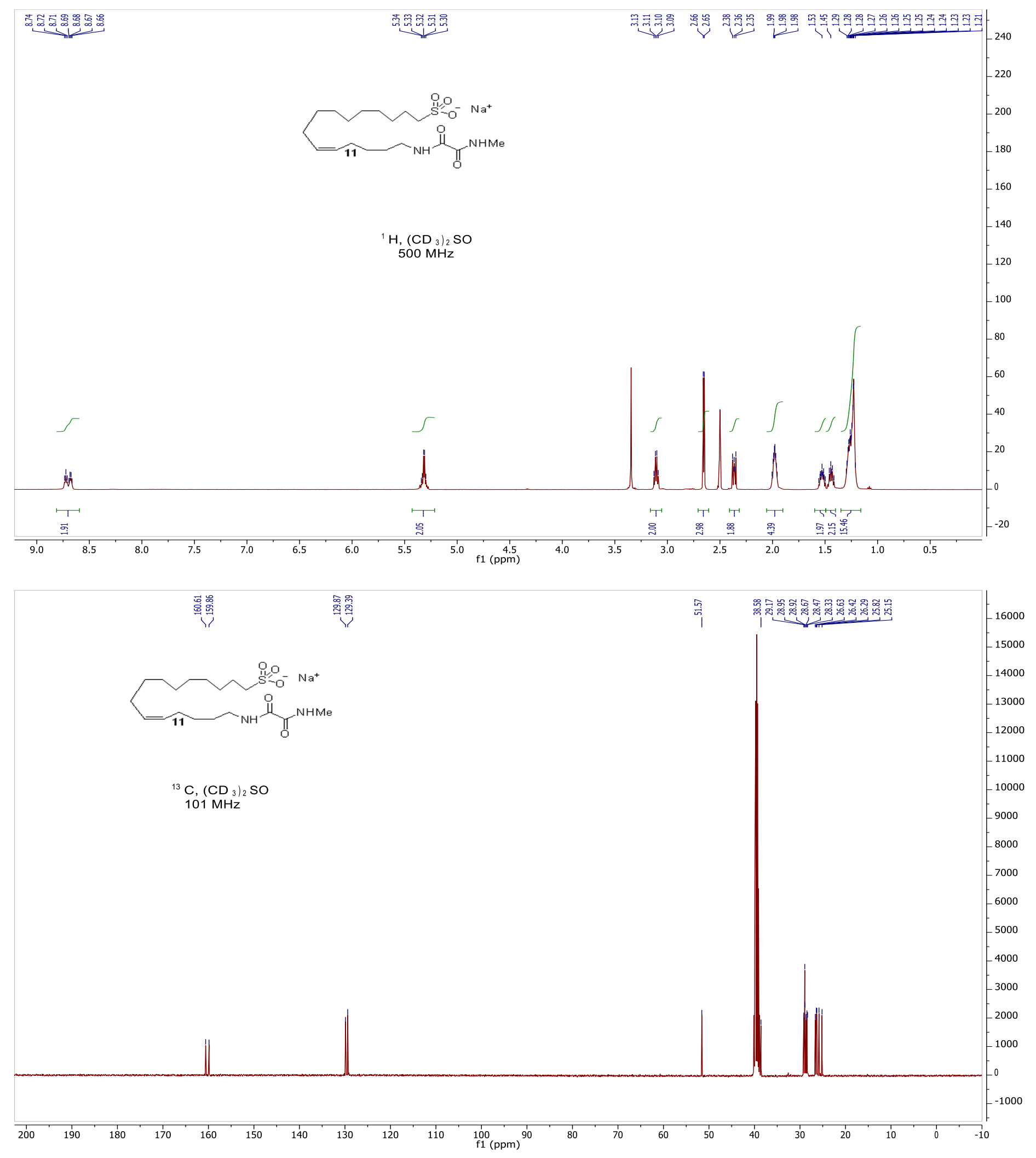




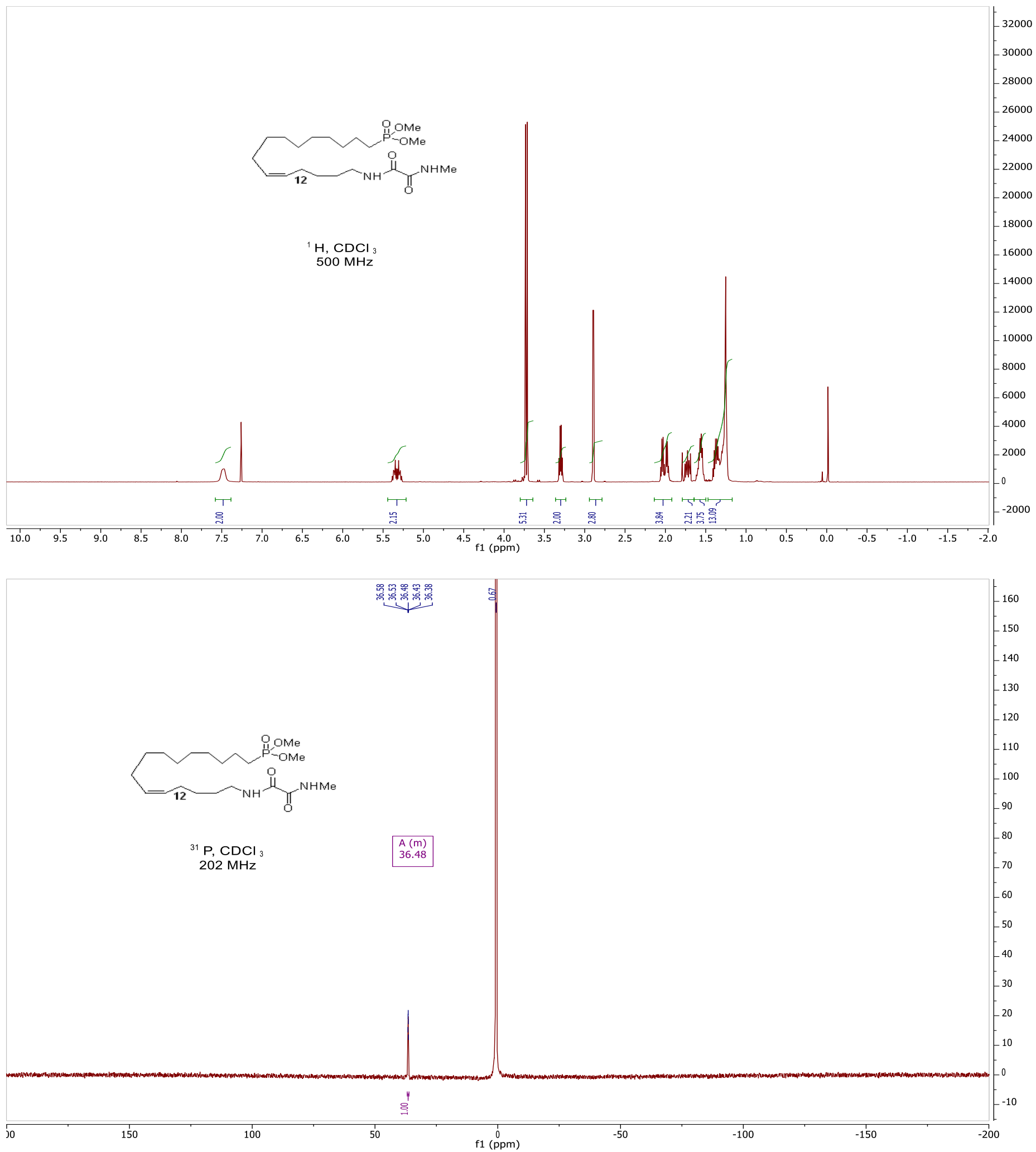




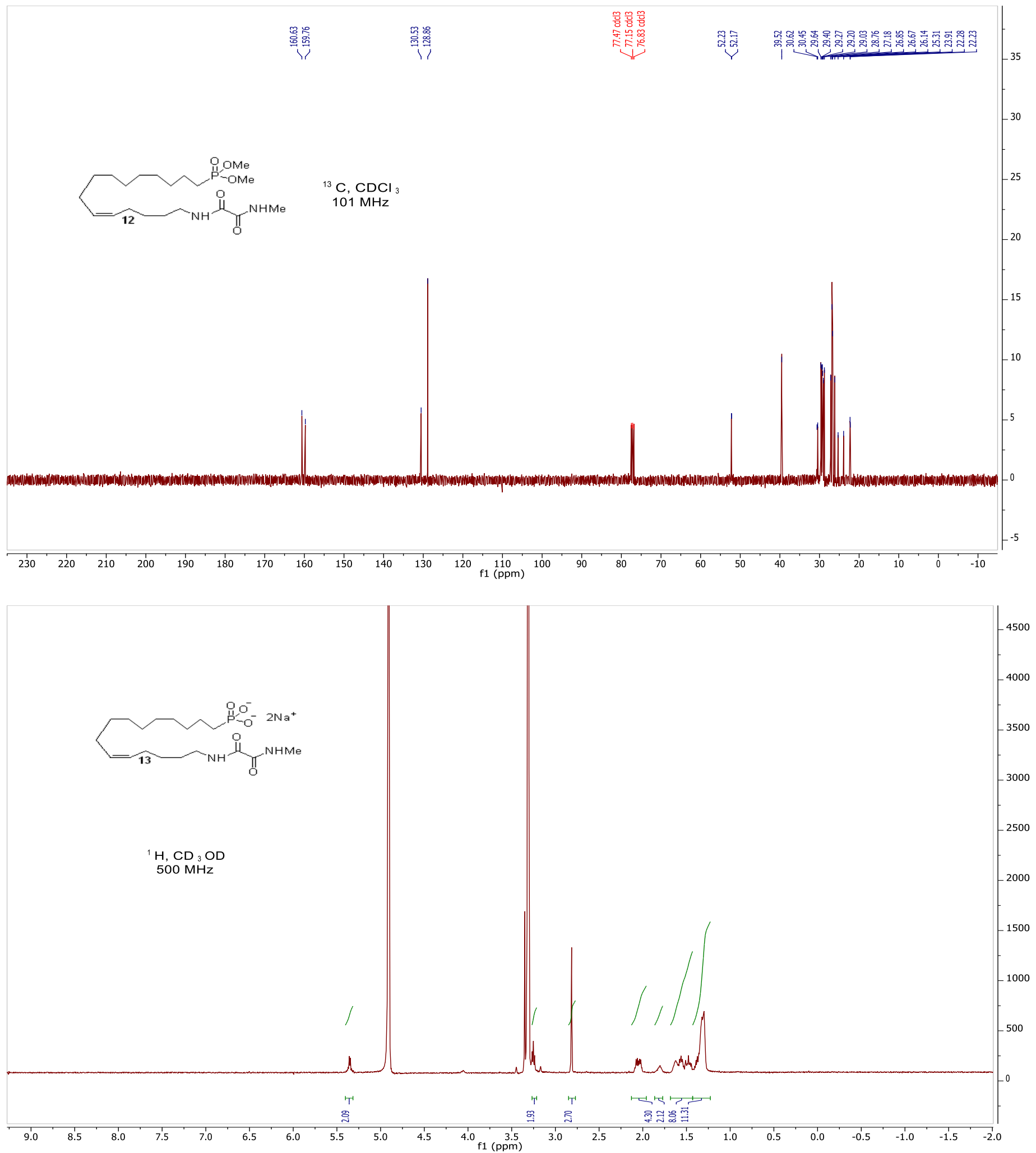





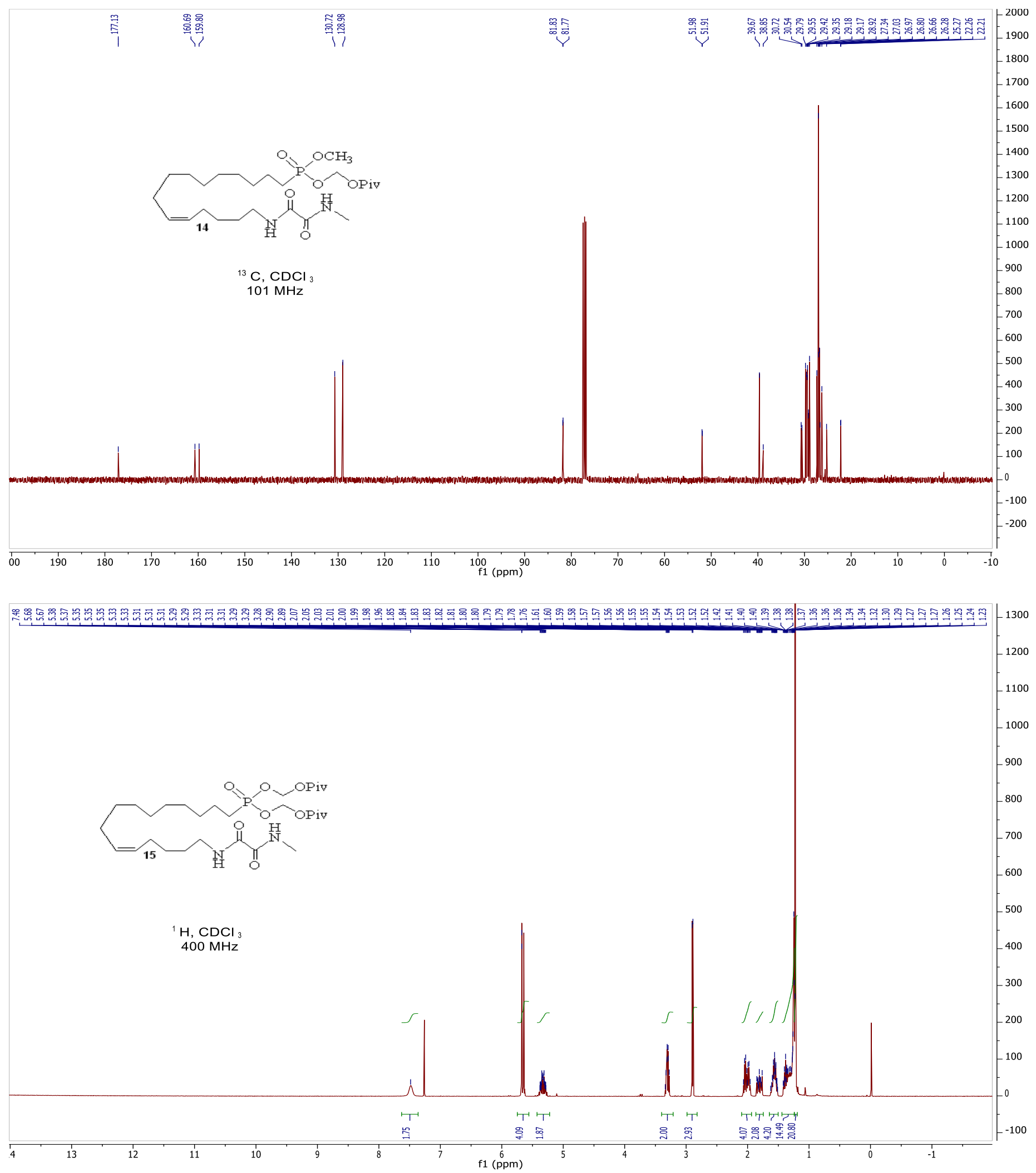

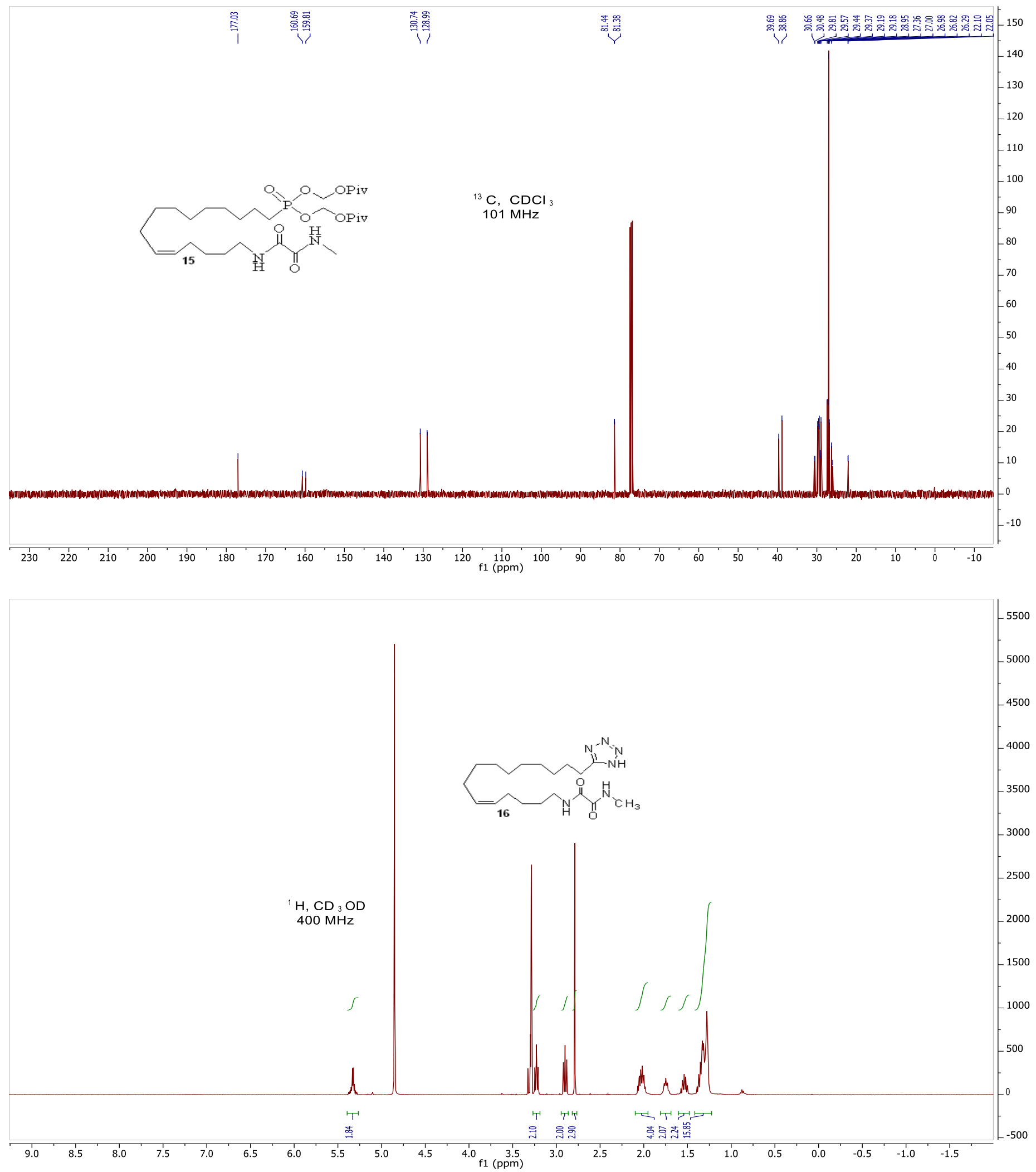

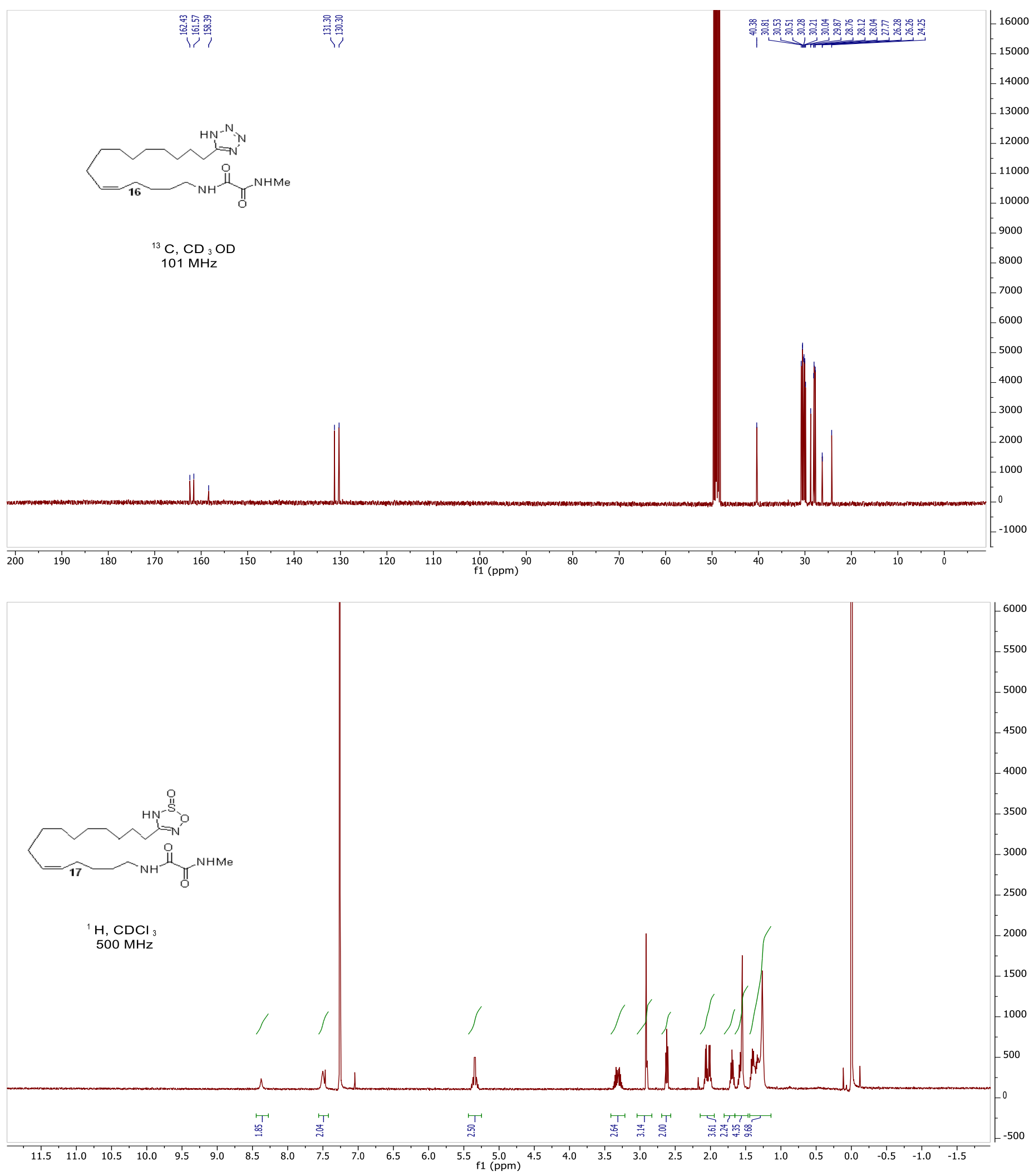


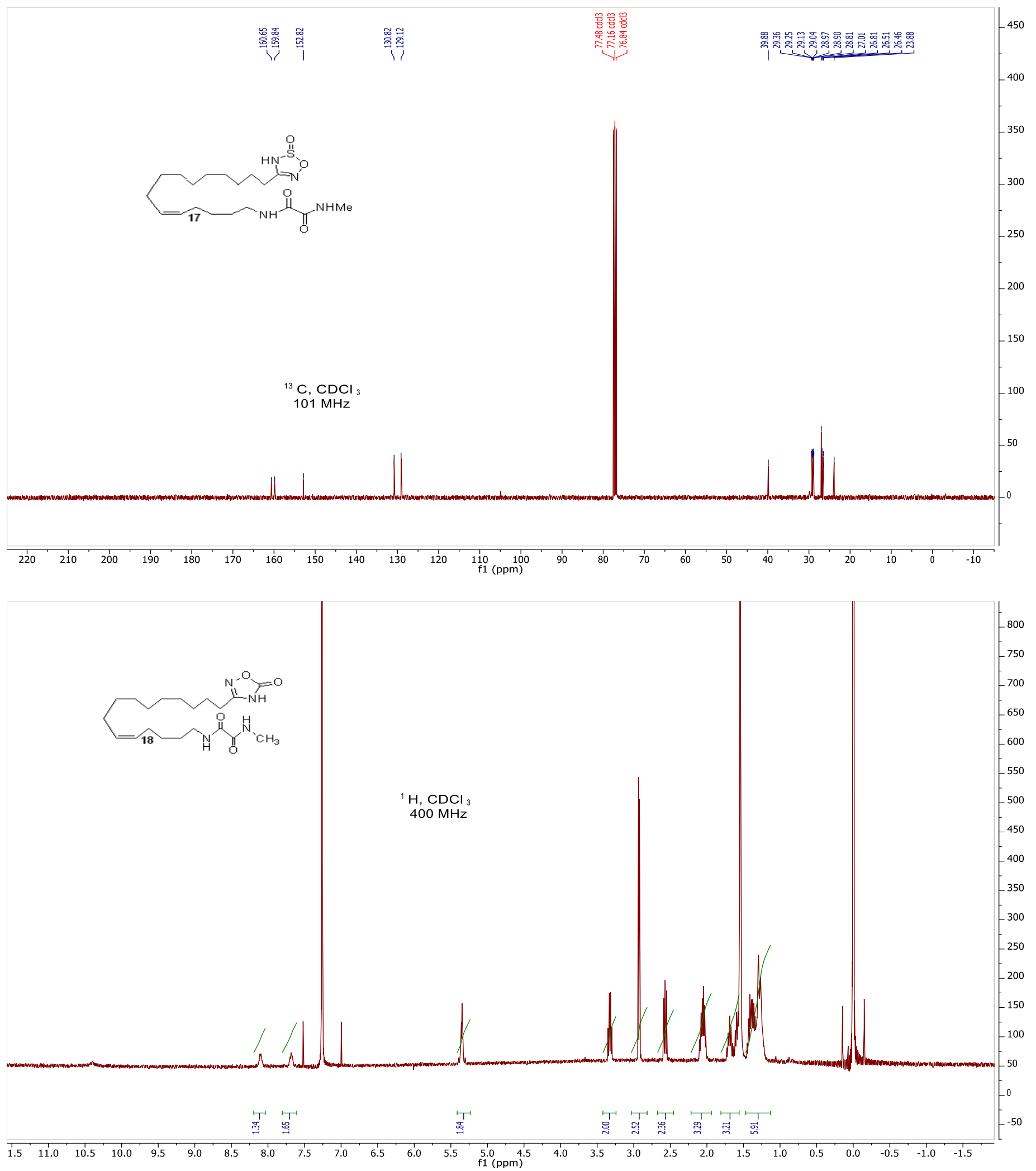



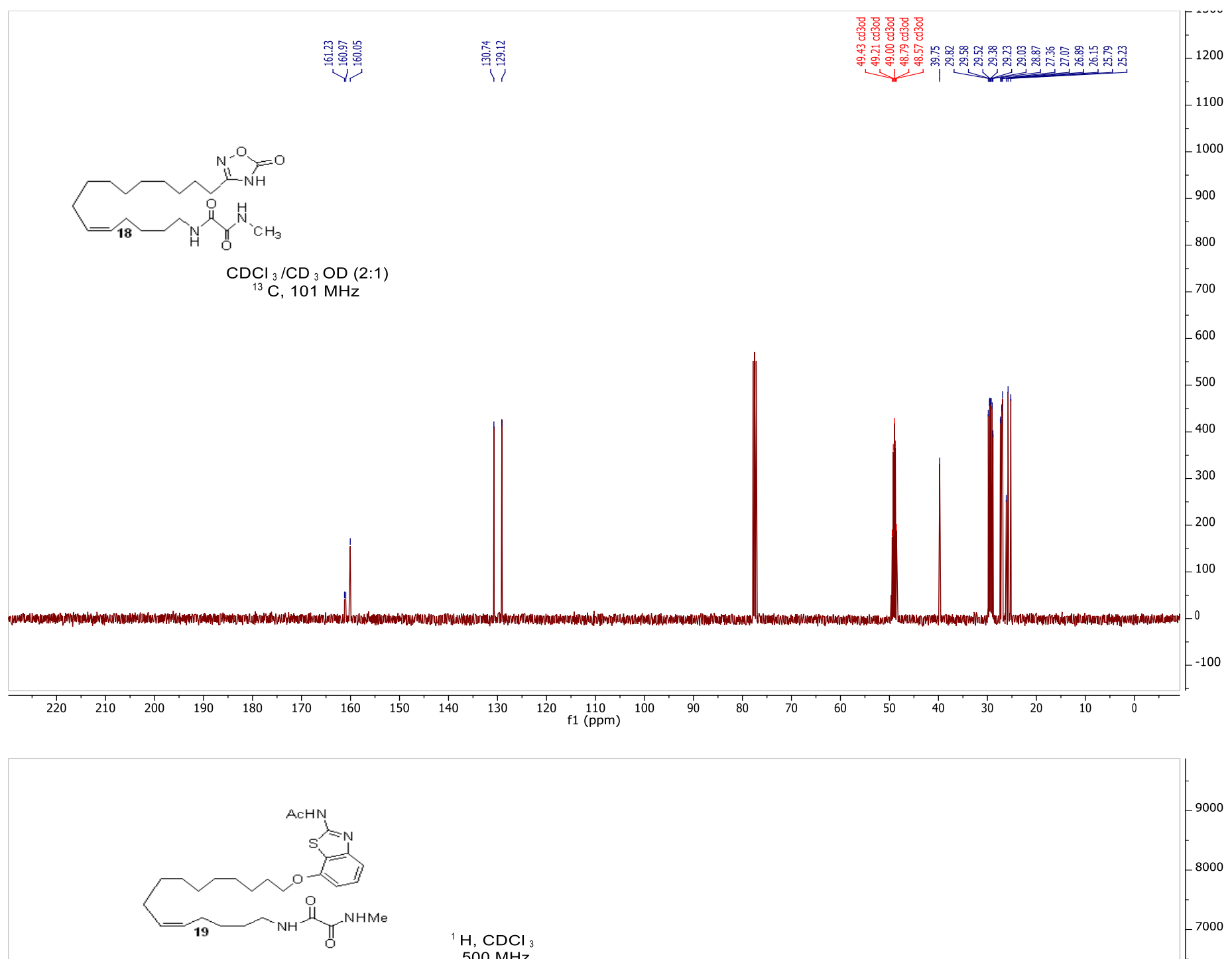

${ }^{1} \mathrm{H}, \mathrm{CDCl}_{3}$

$500 \mathrm{MHz}$

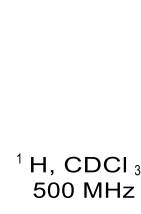

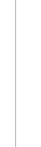

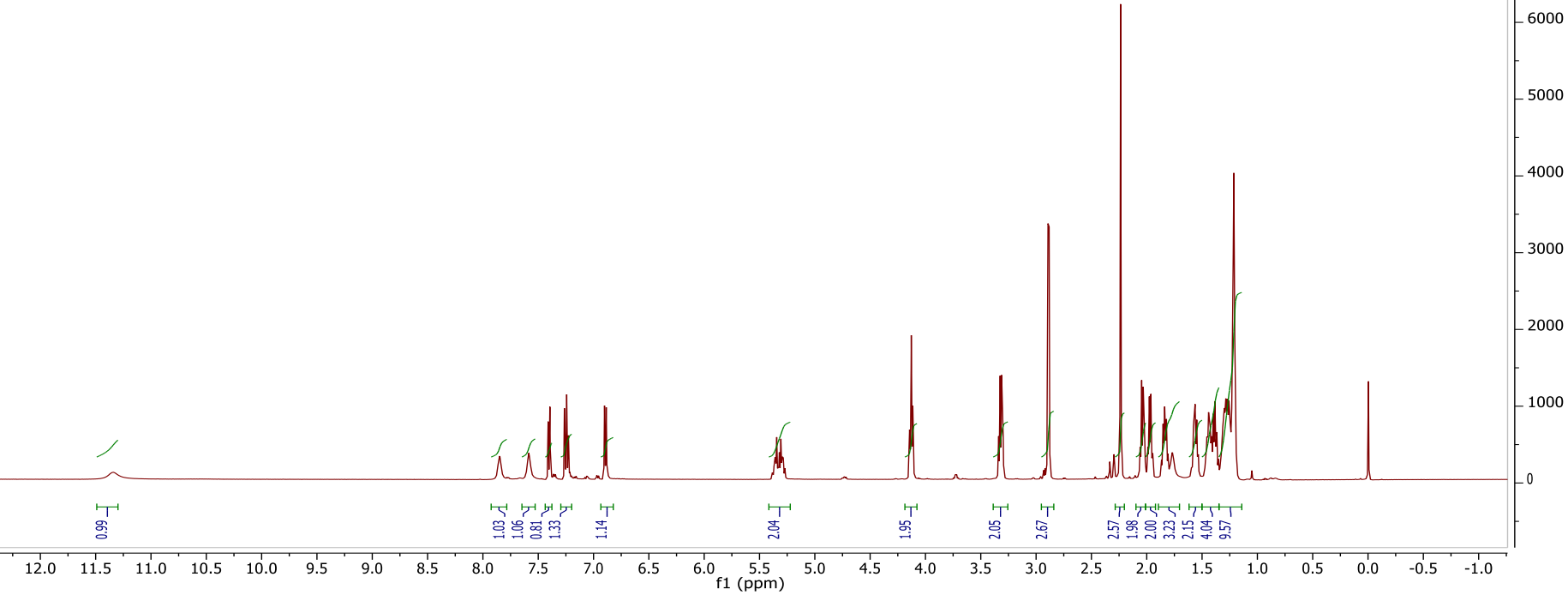



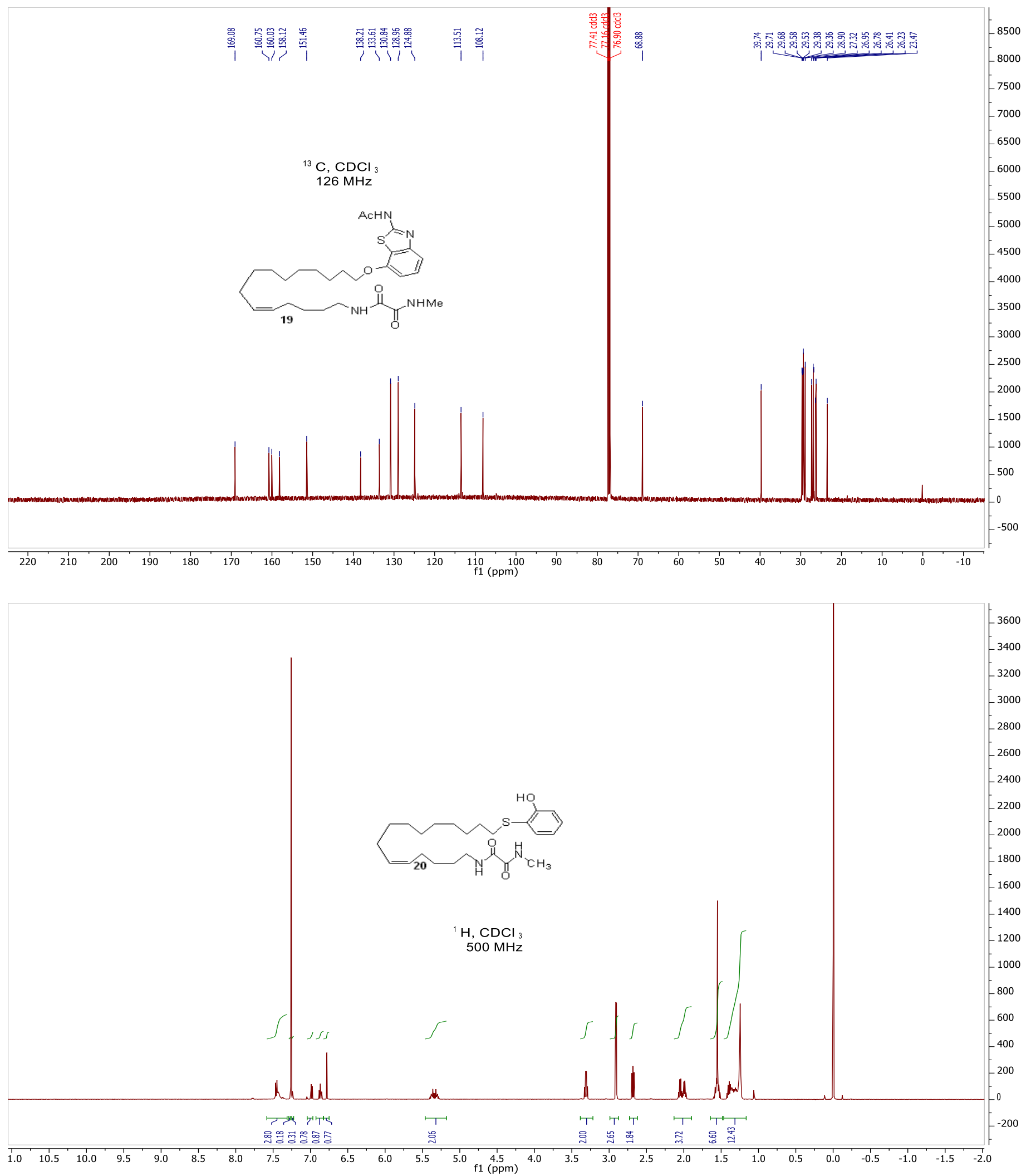

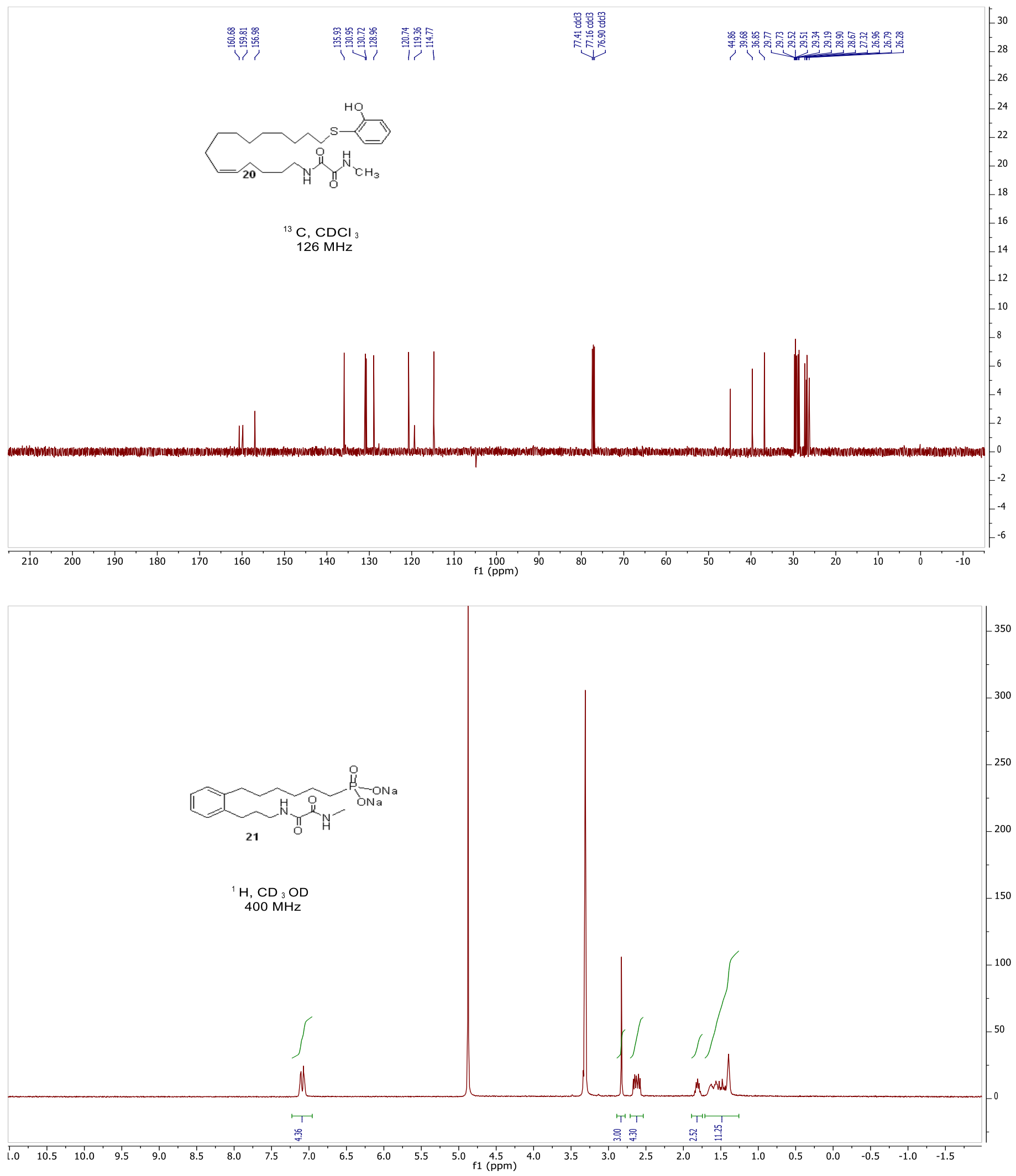

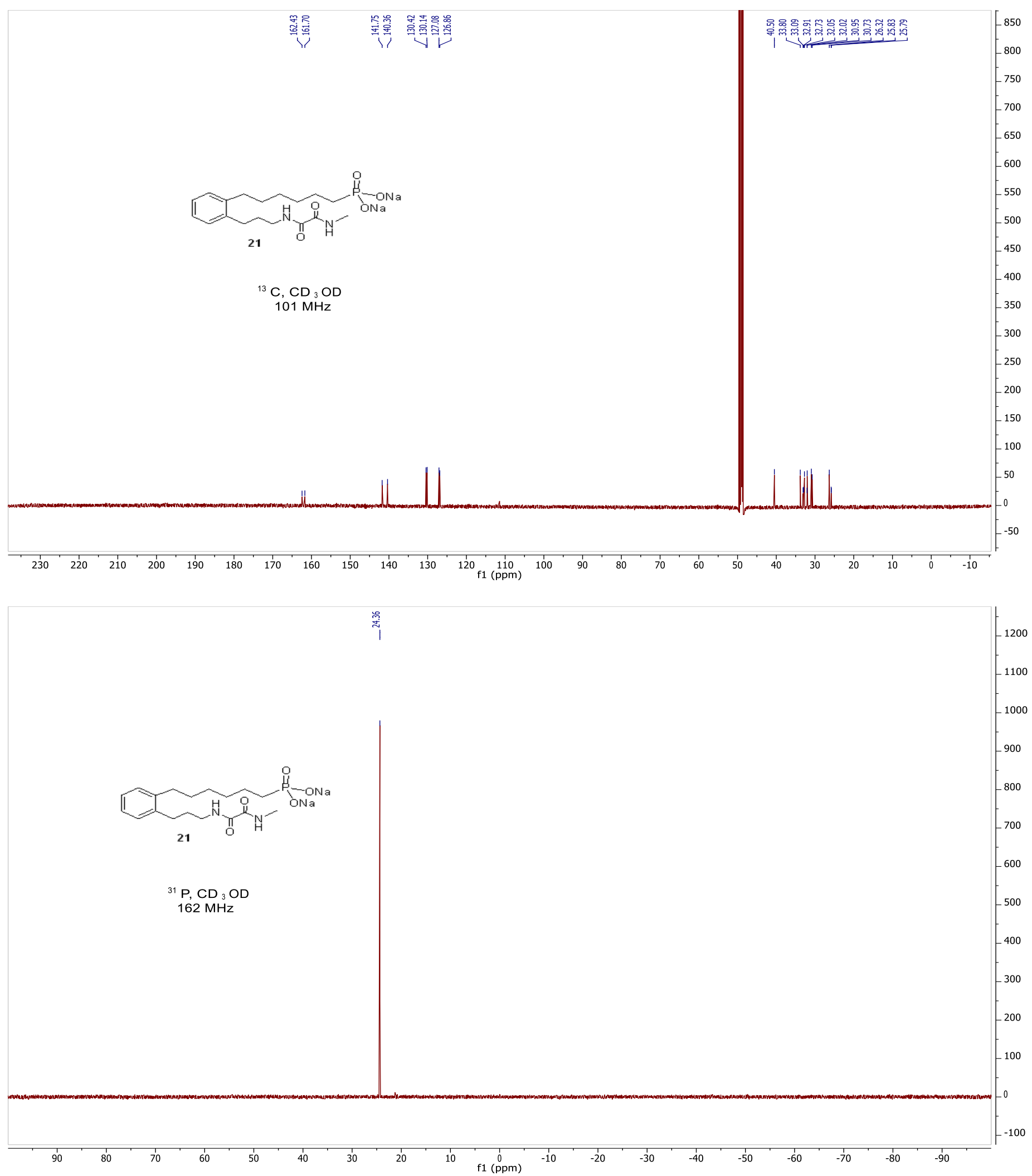


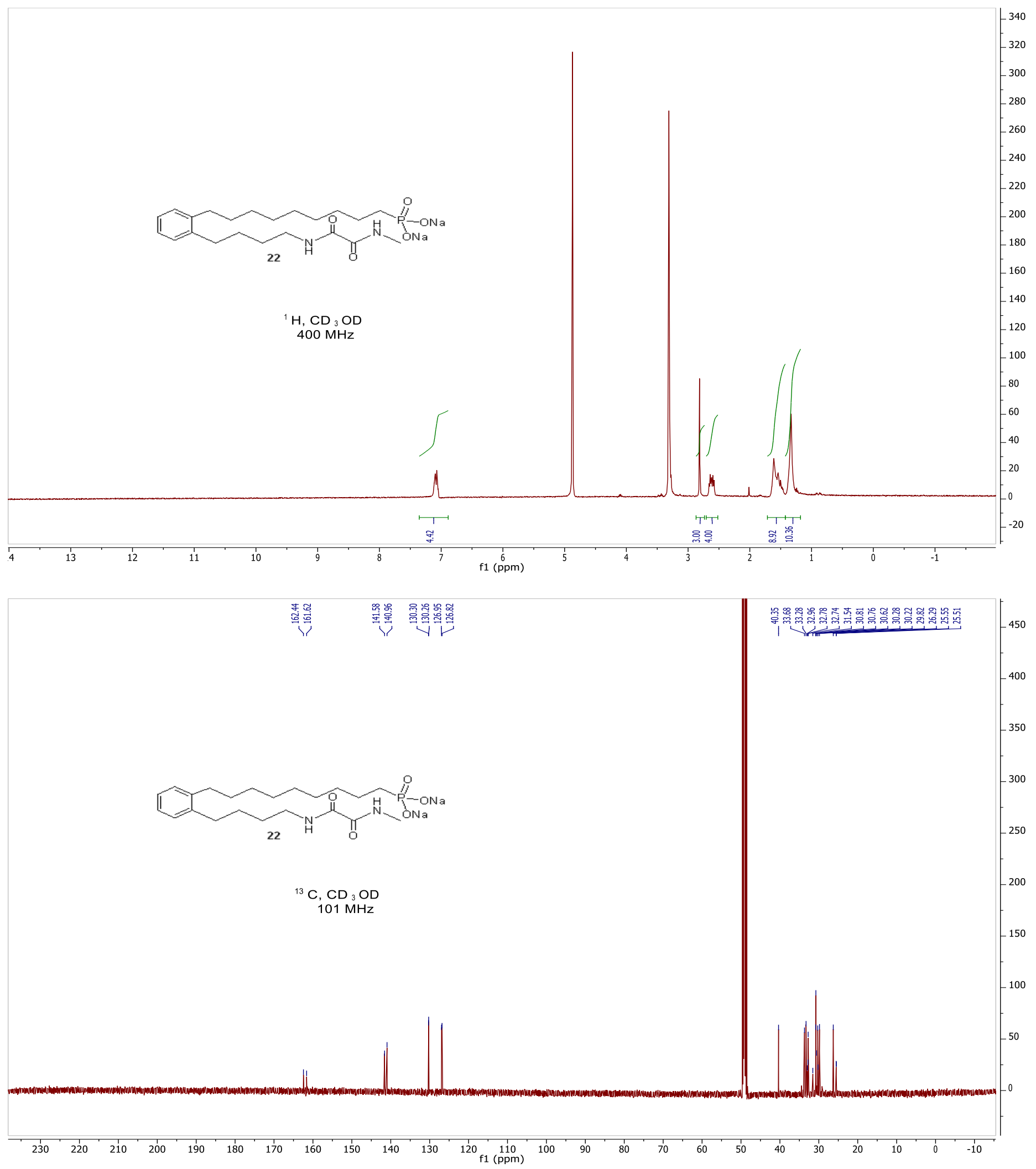



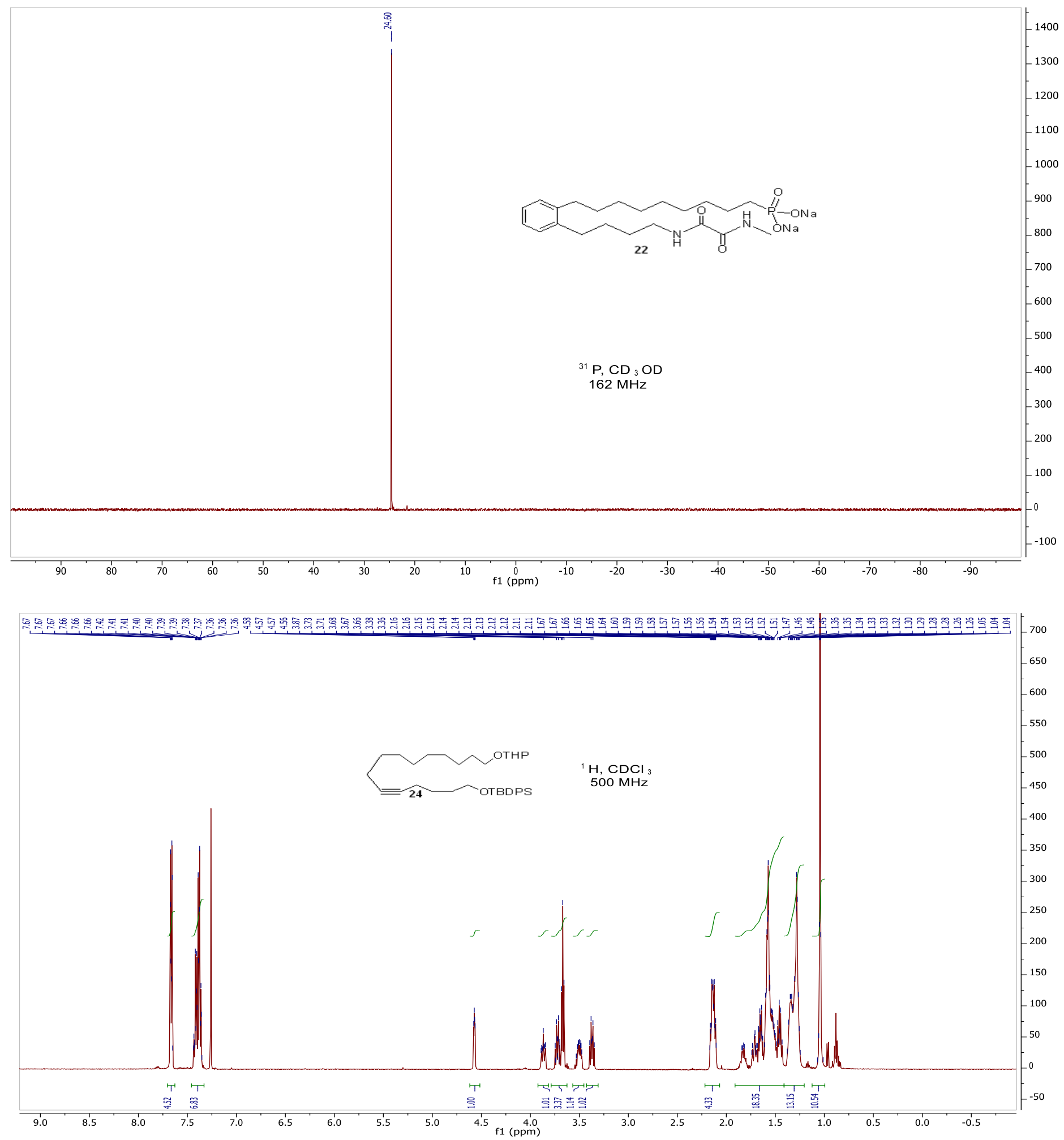


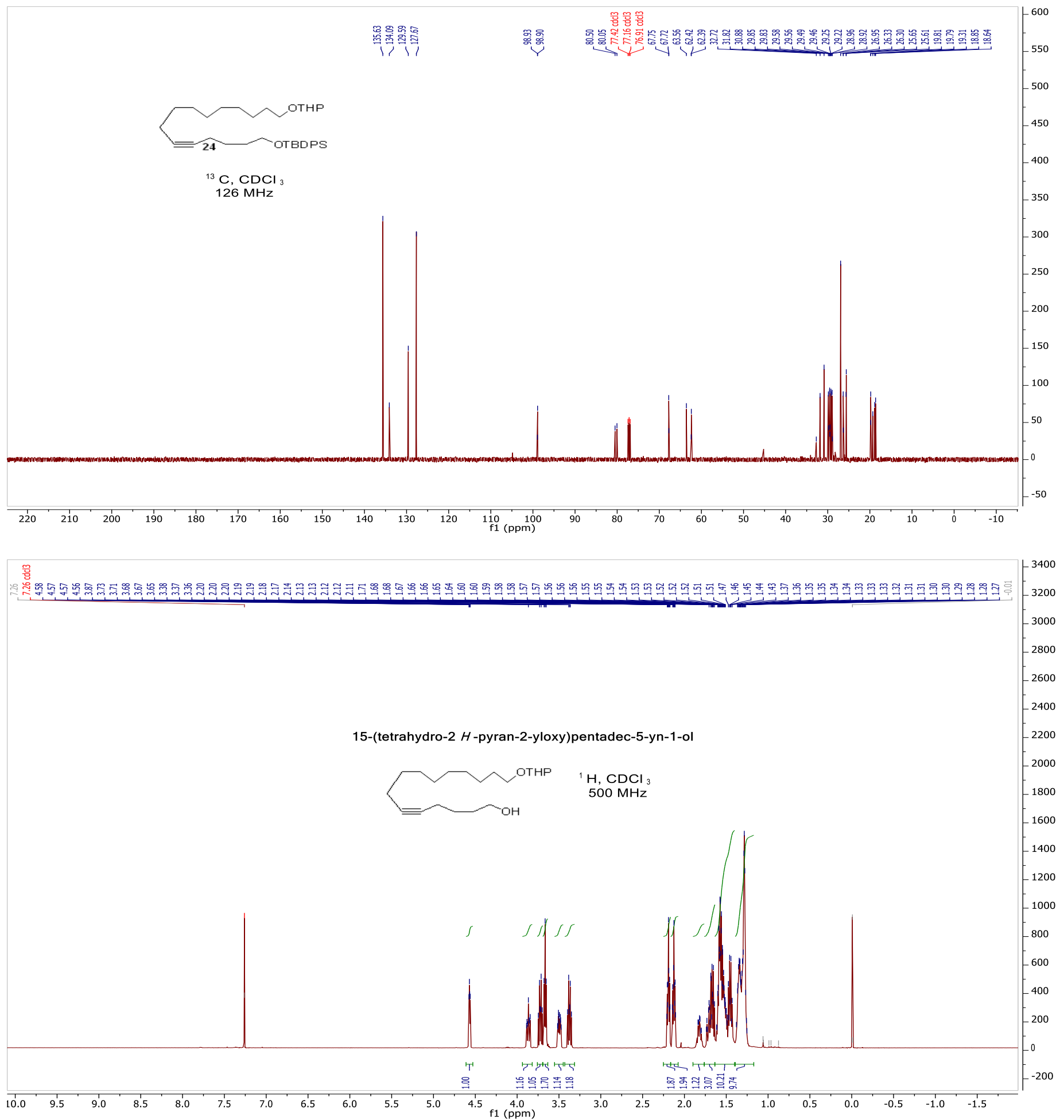




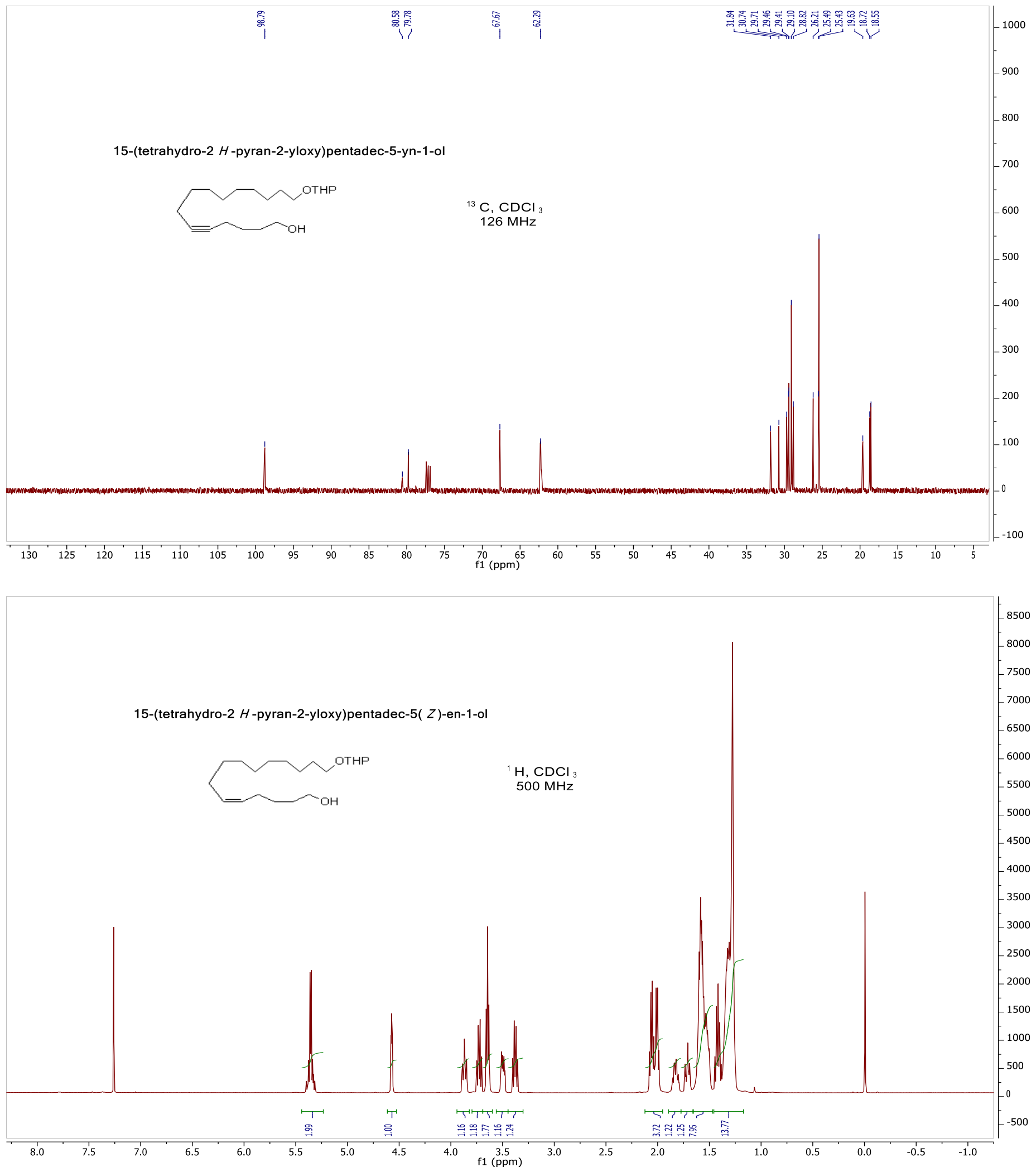




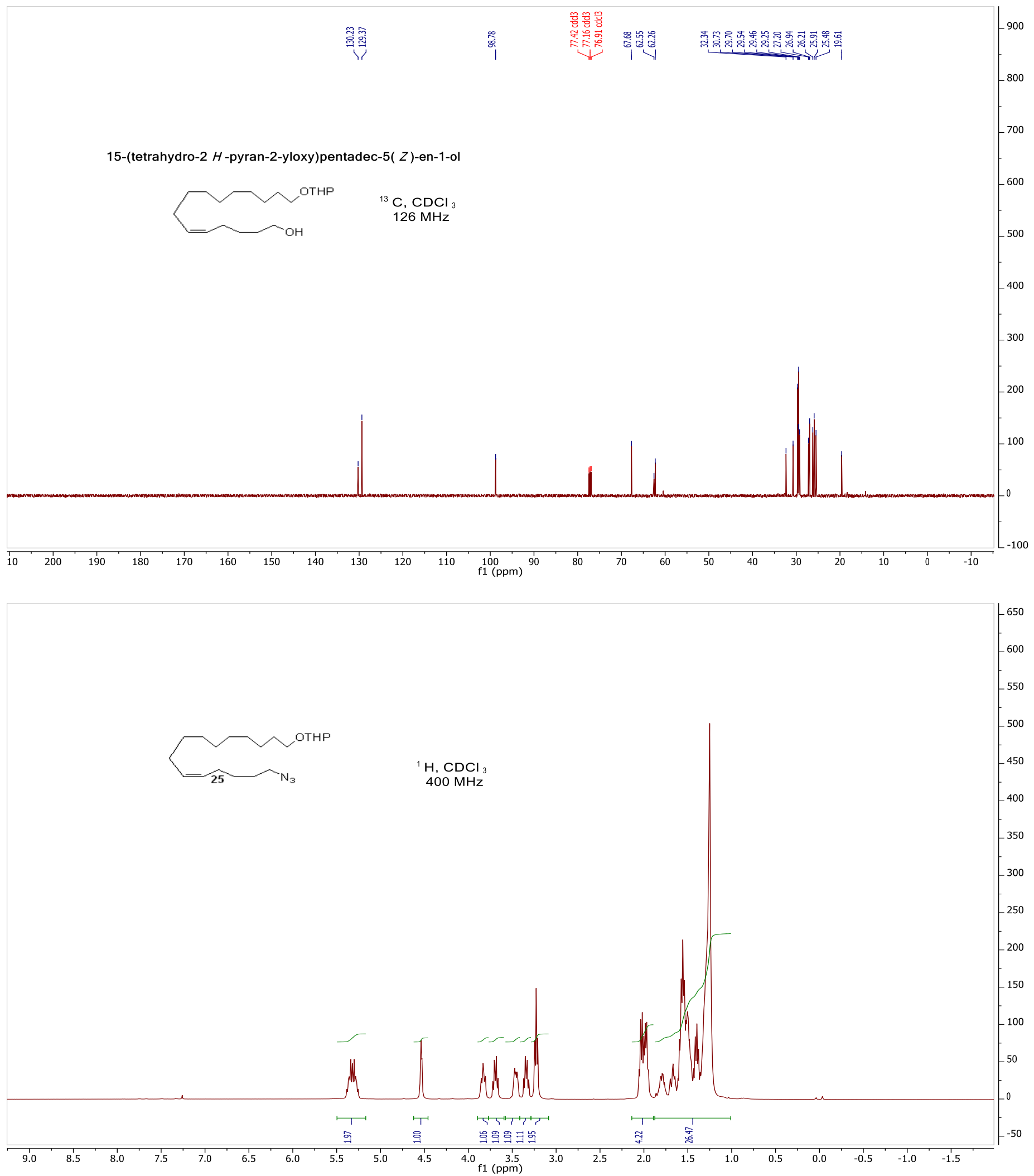




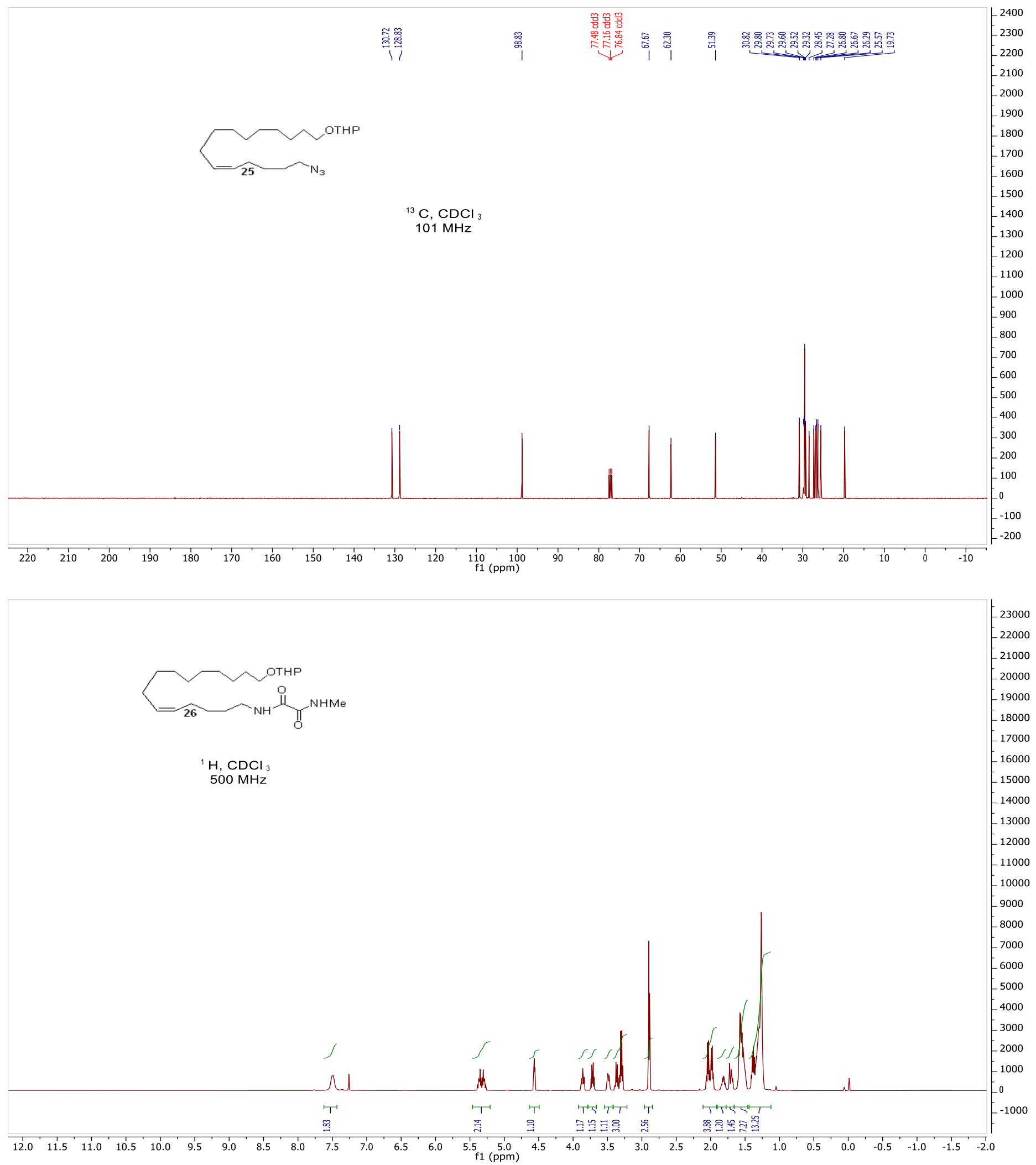




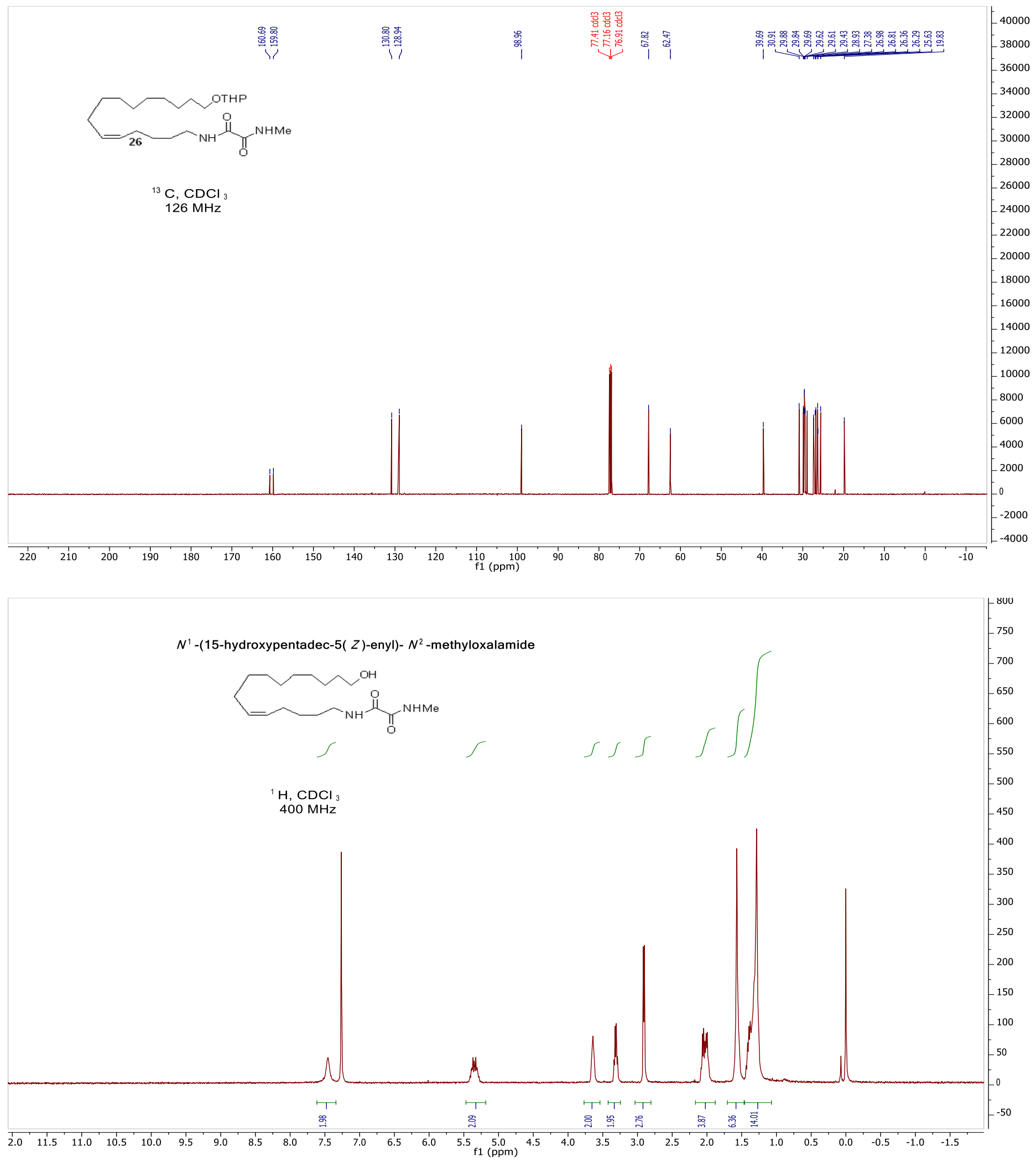



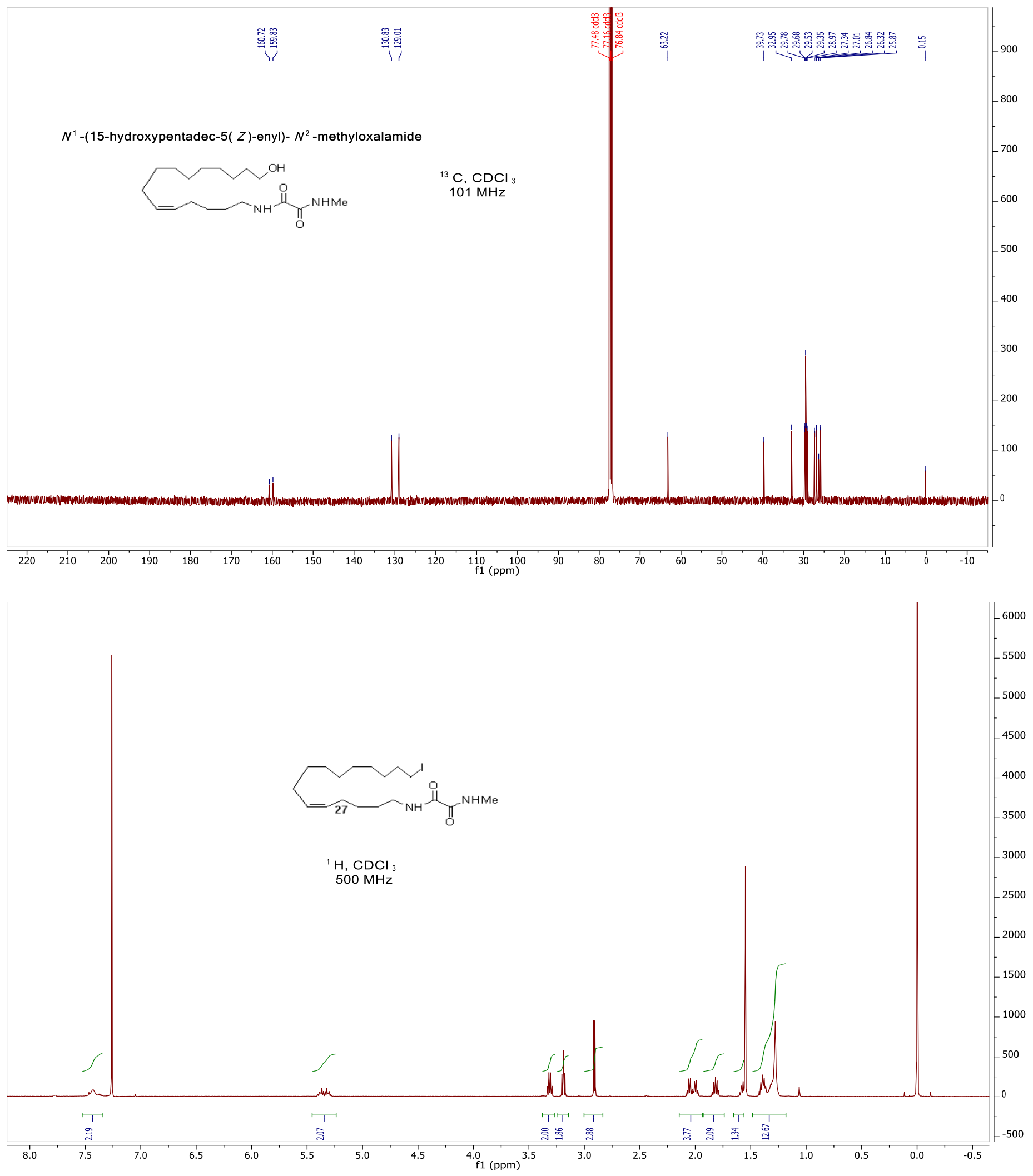

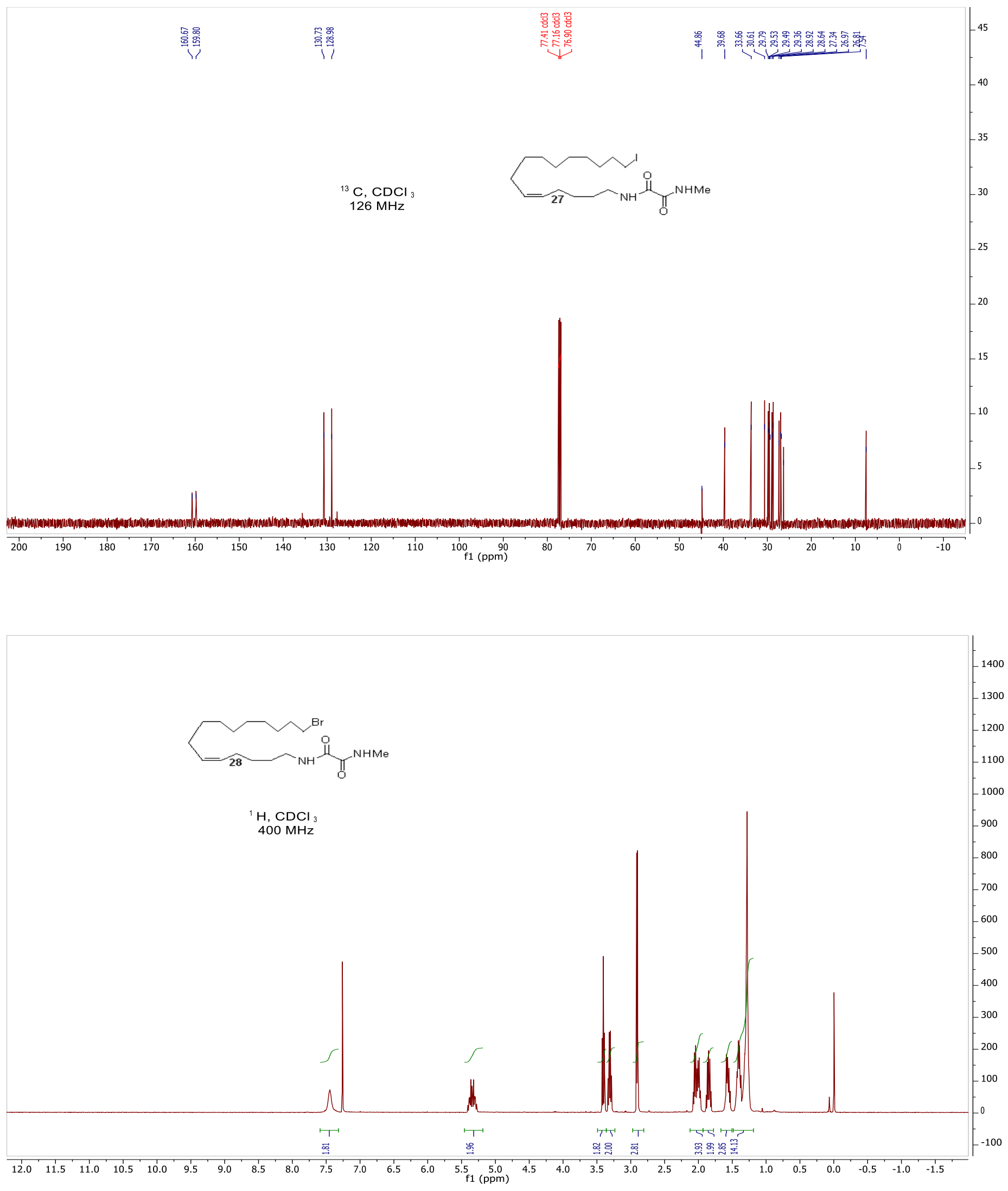

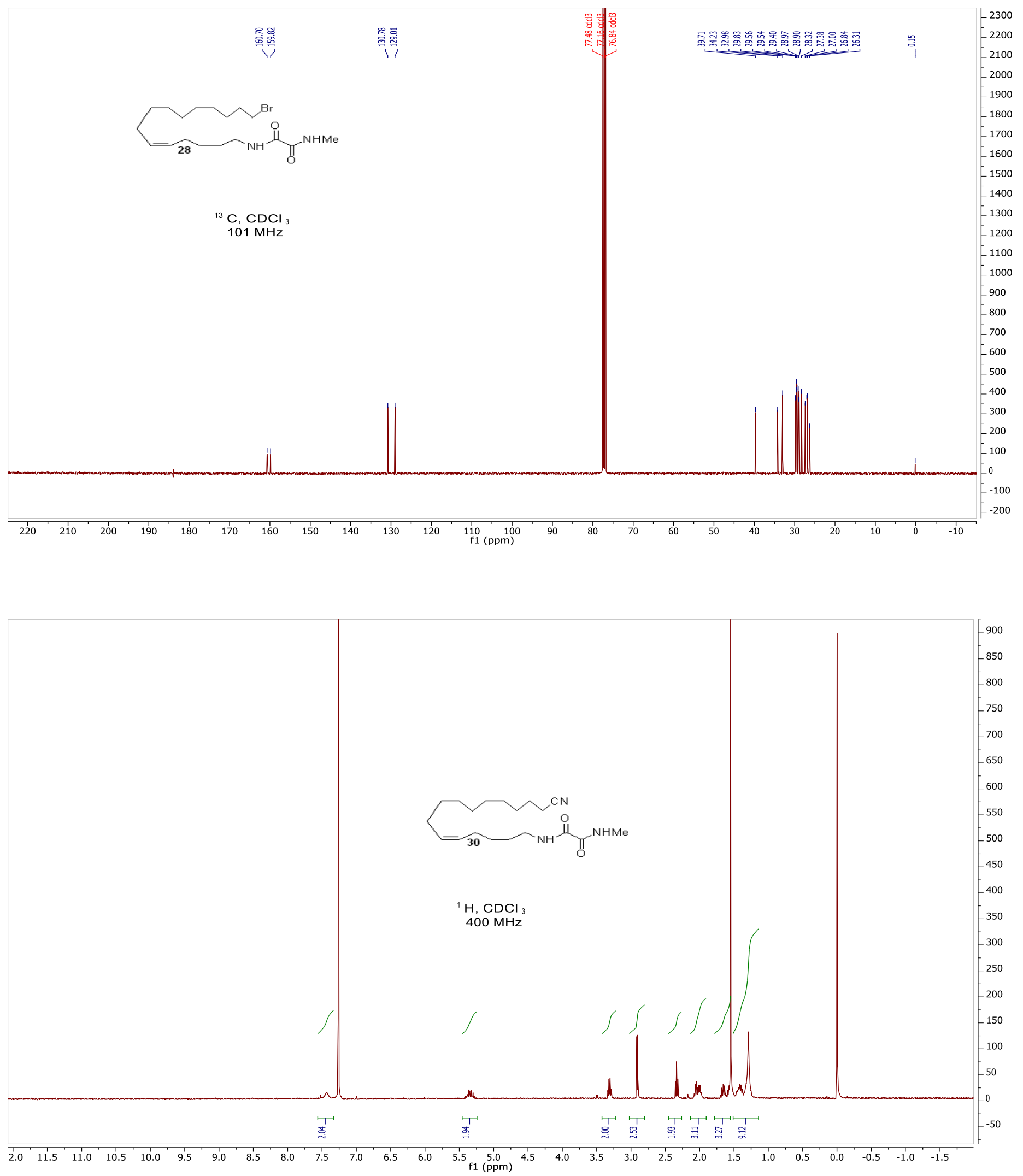

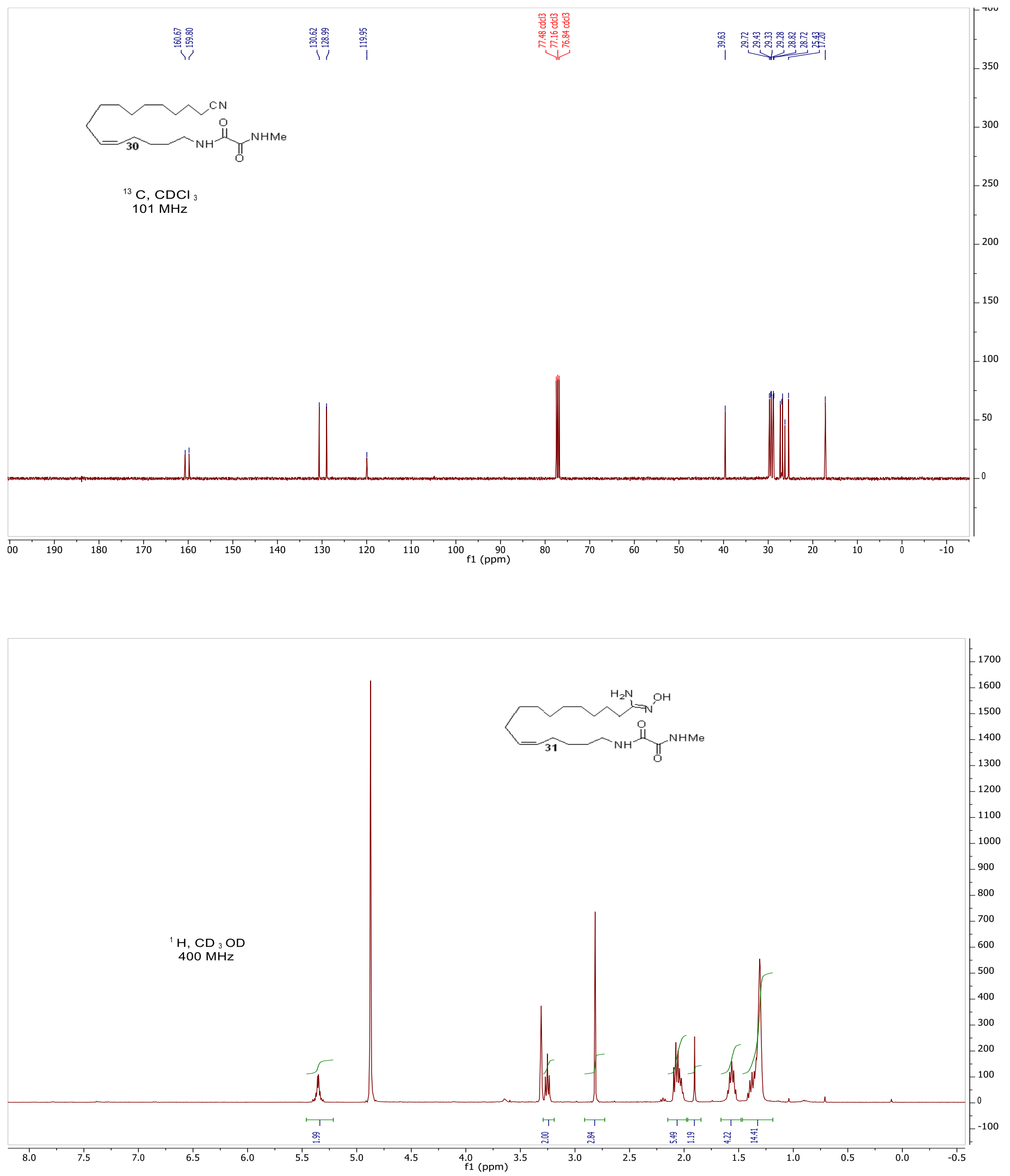

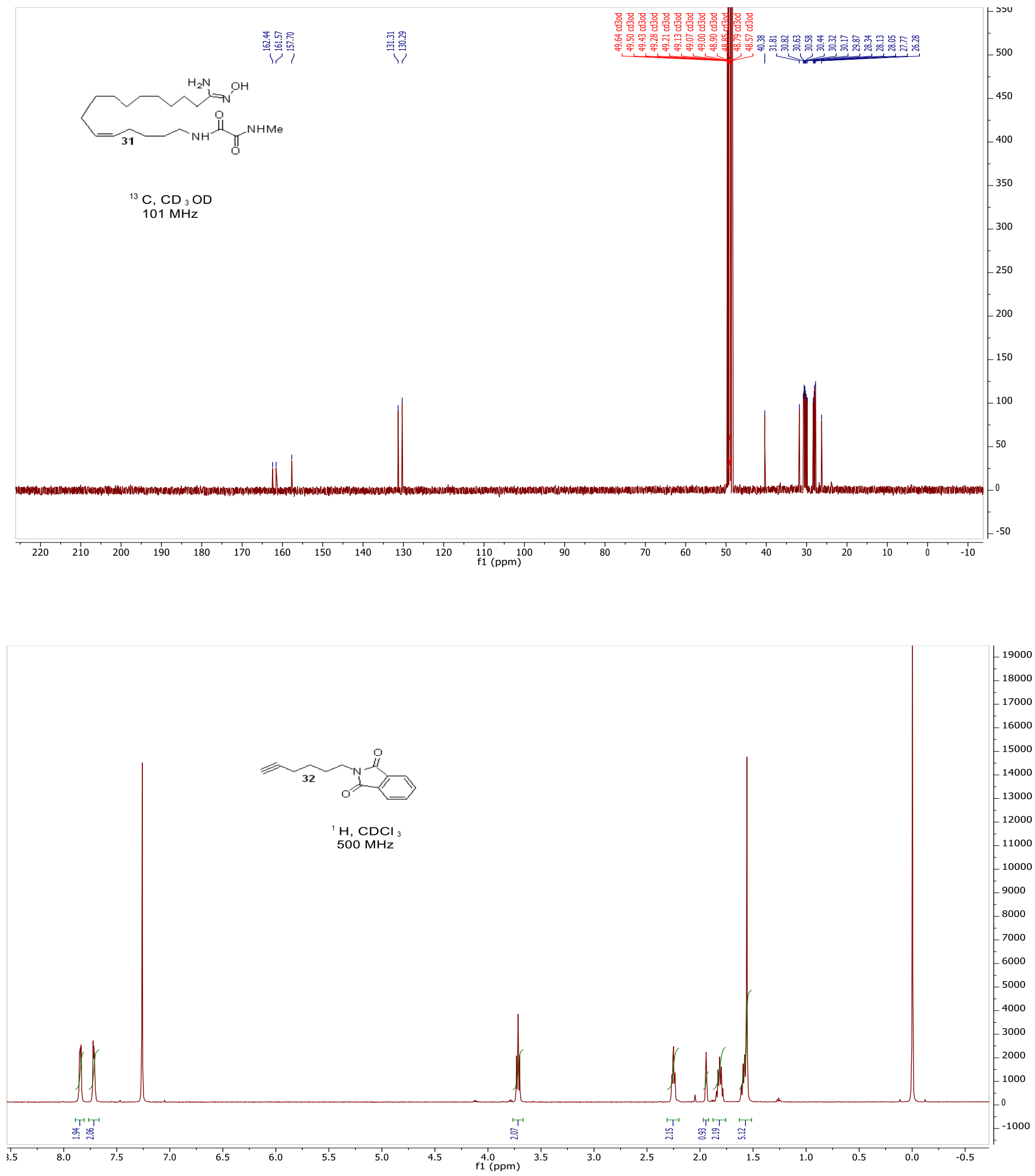


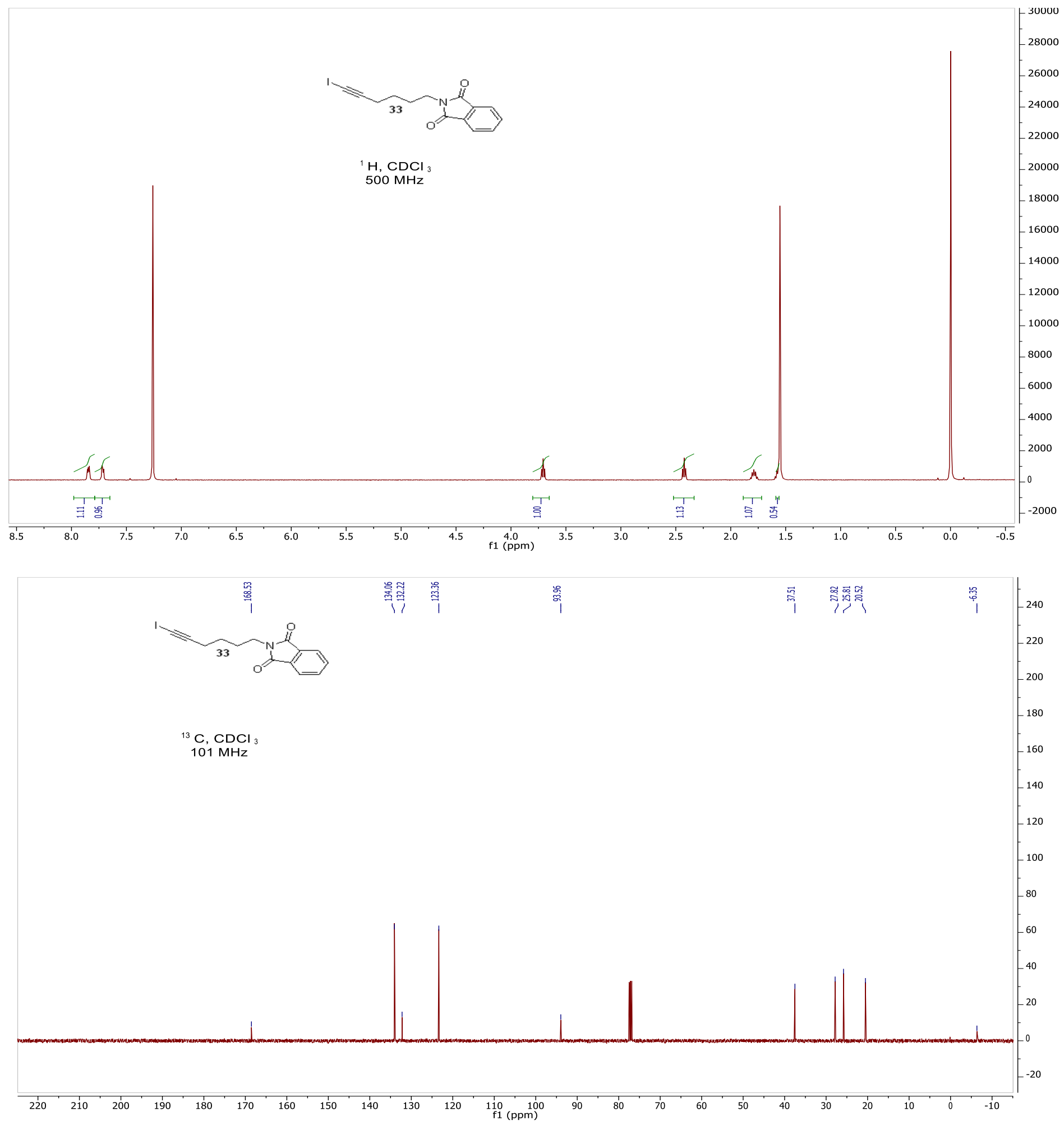




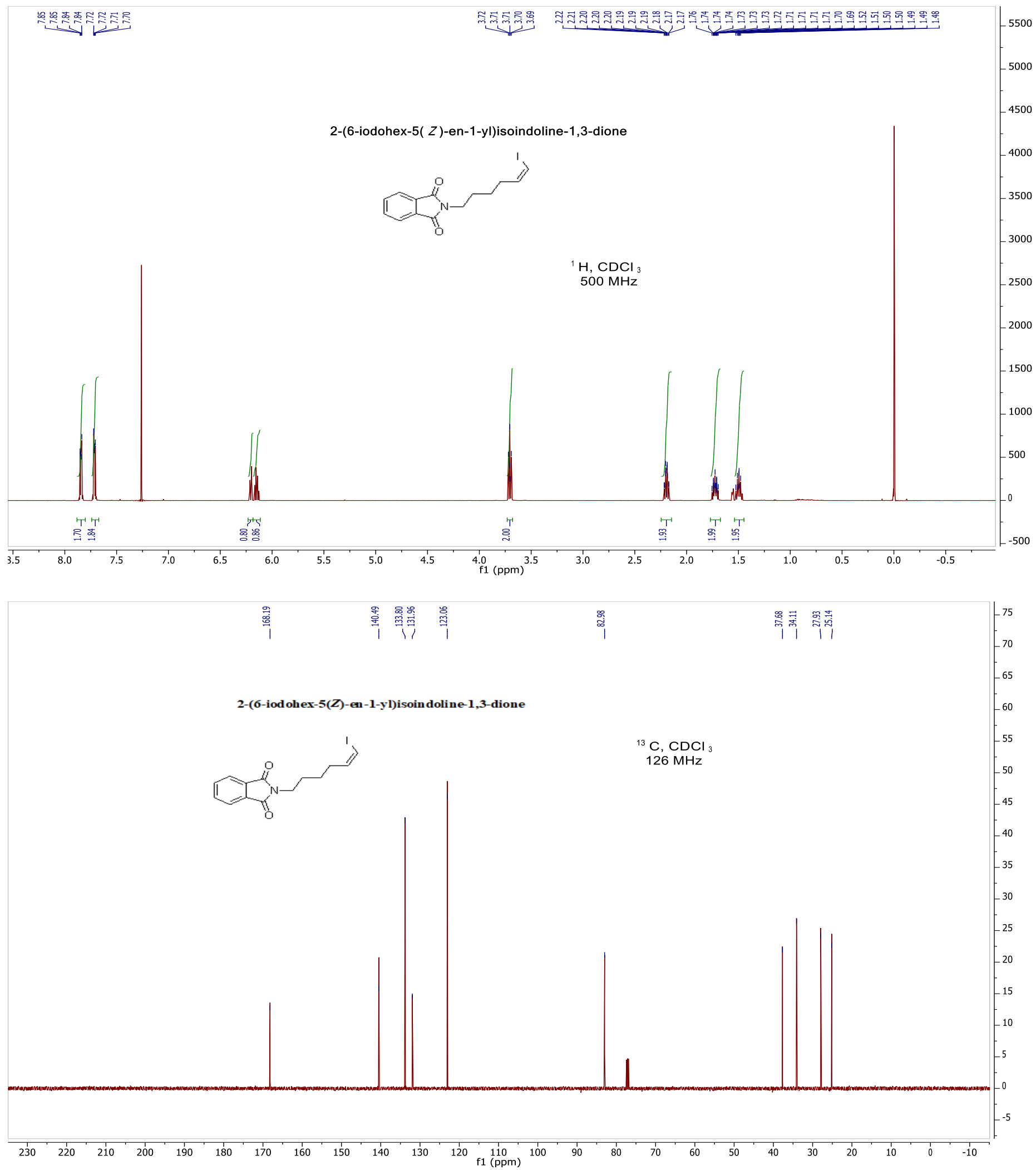



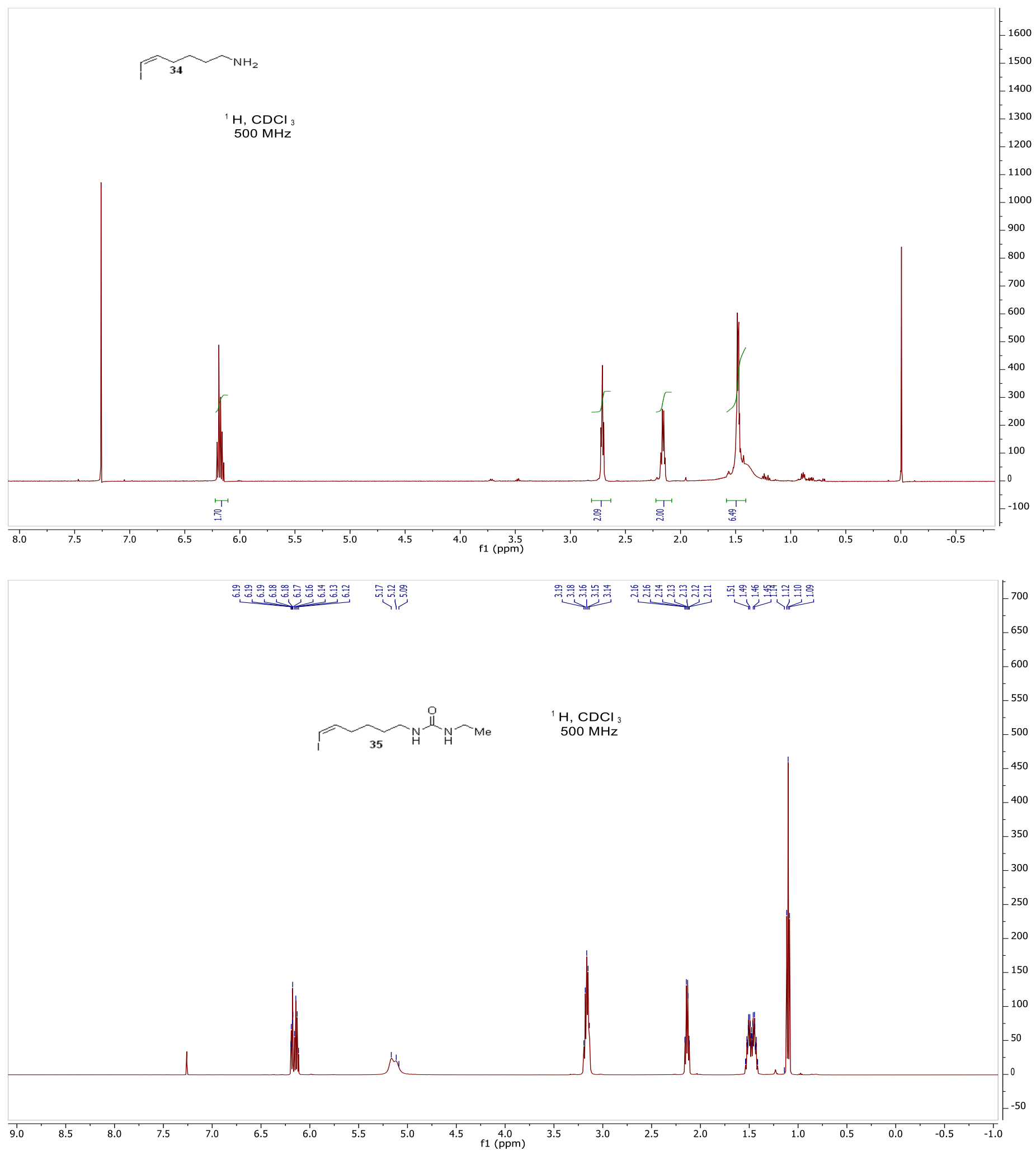

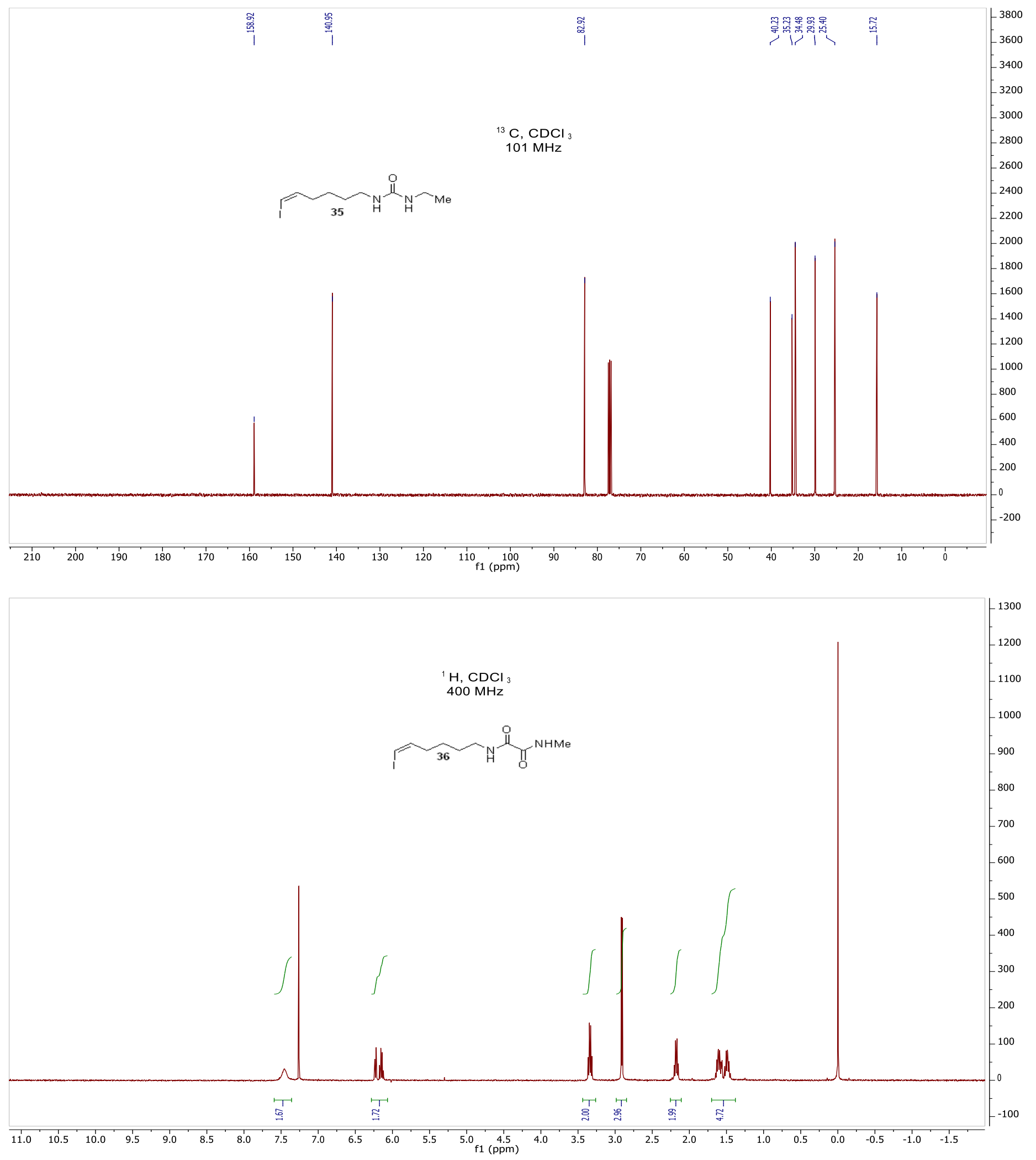

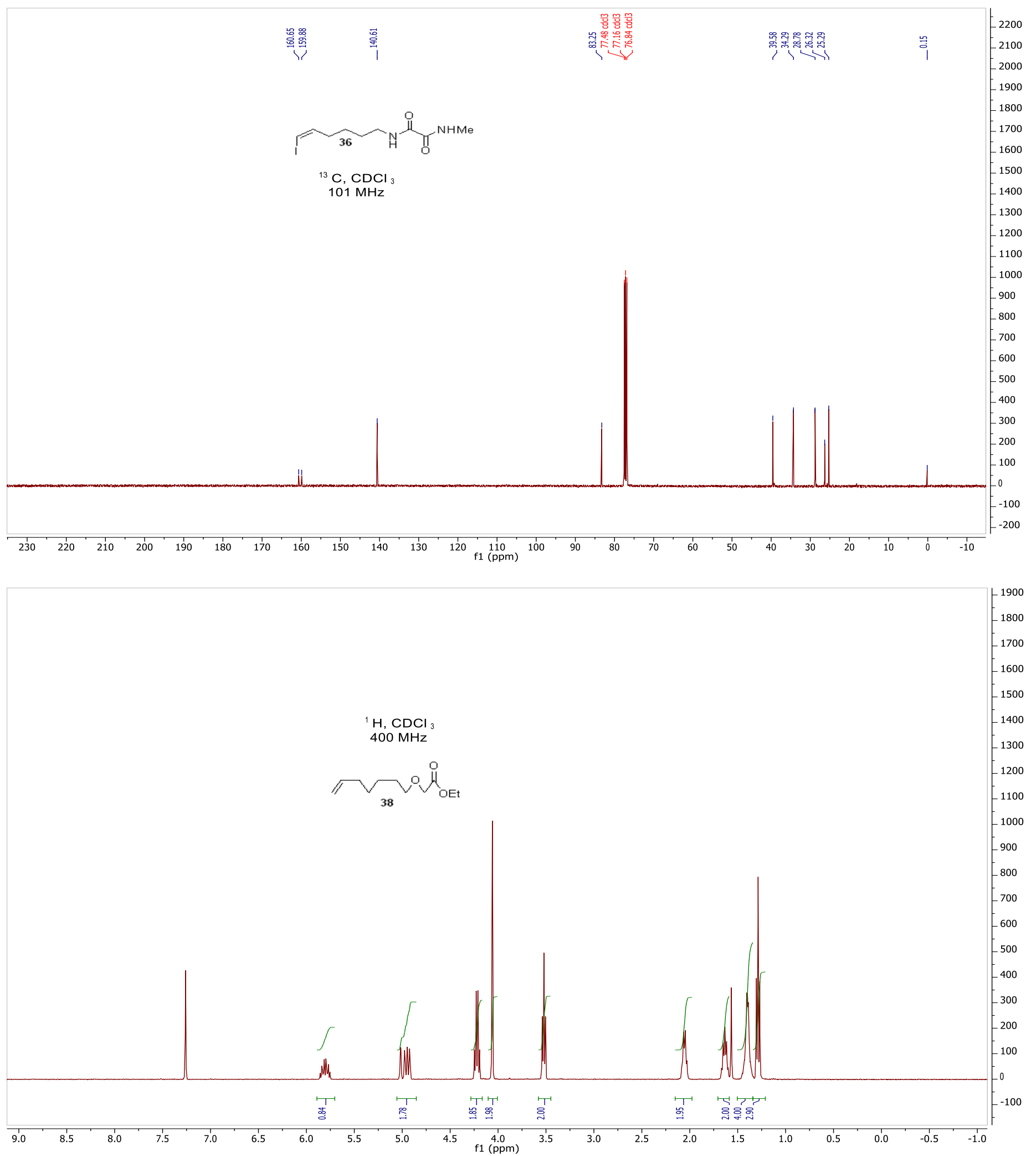

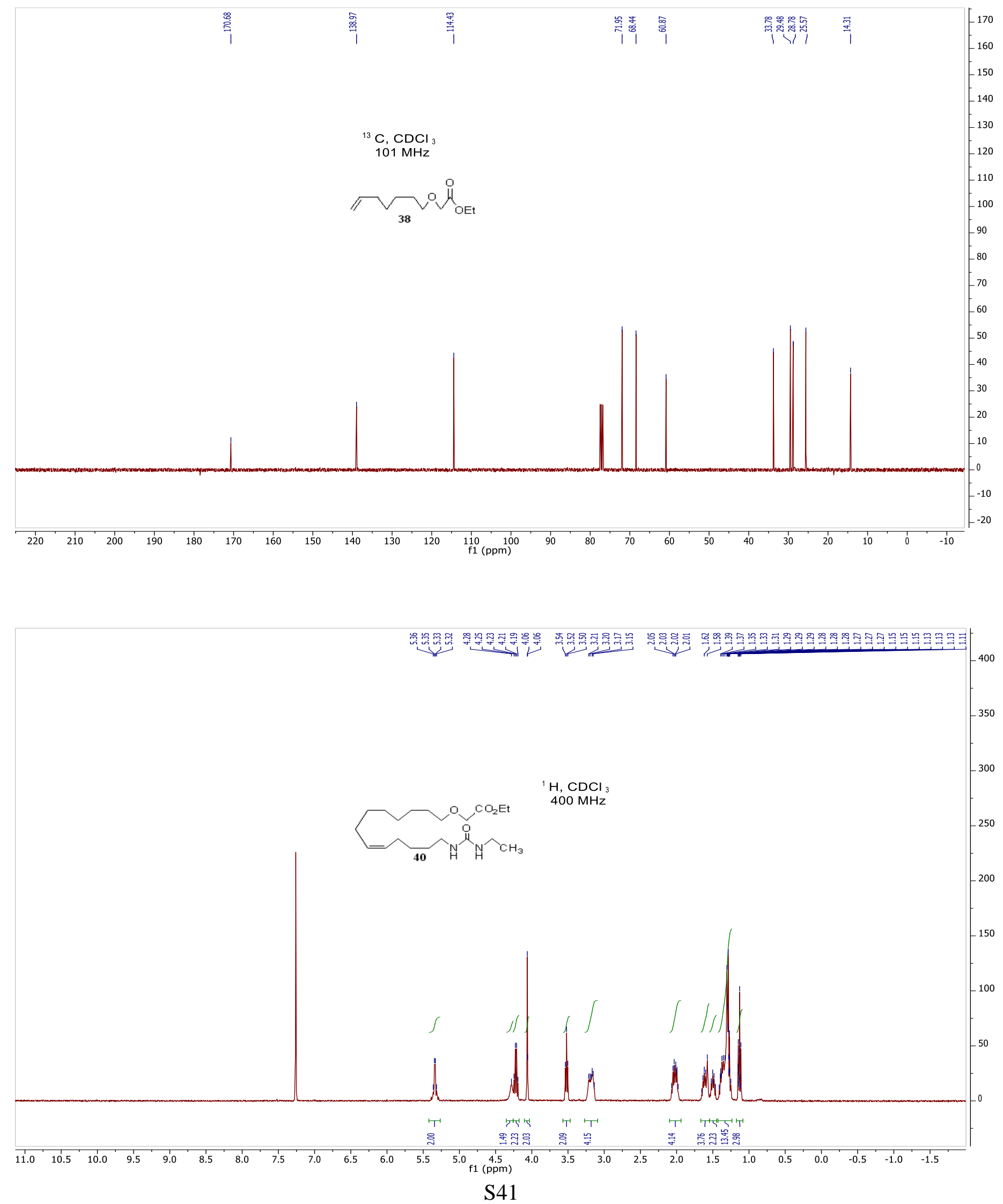

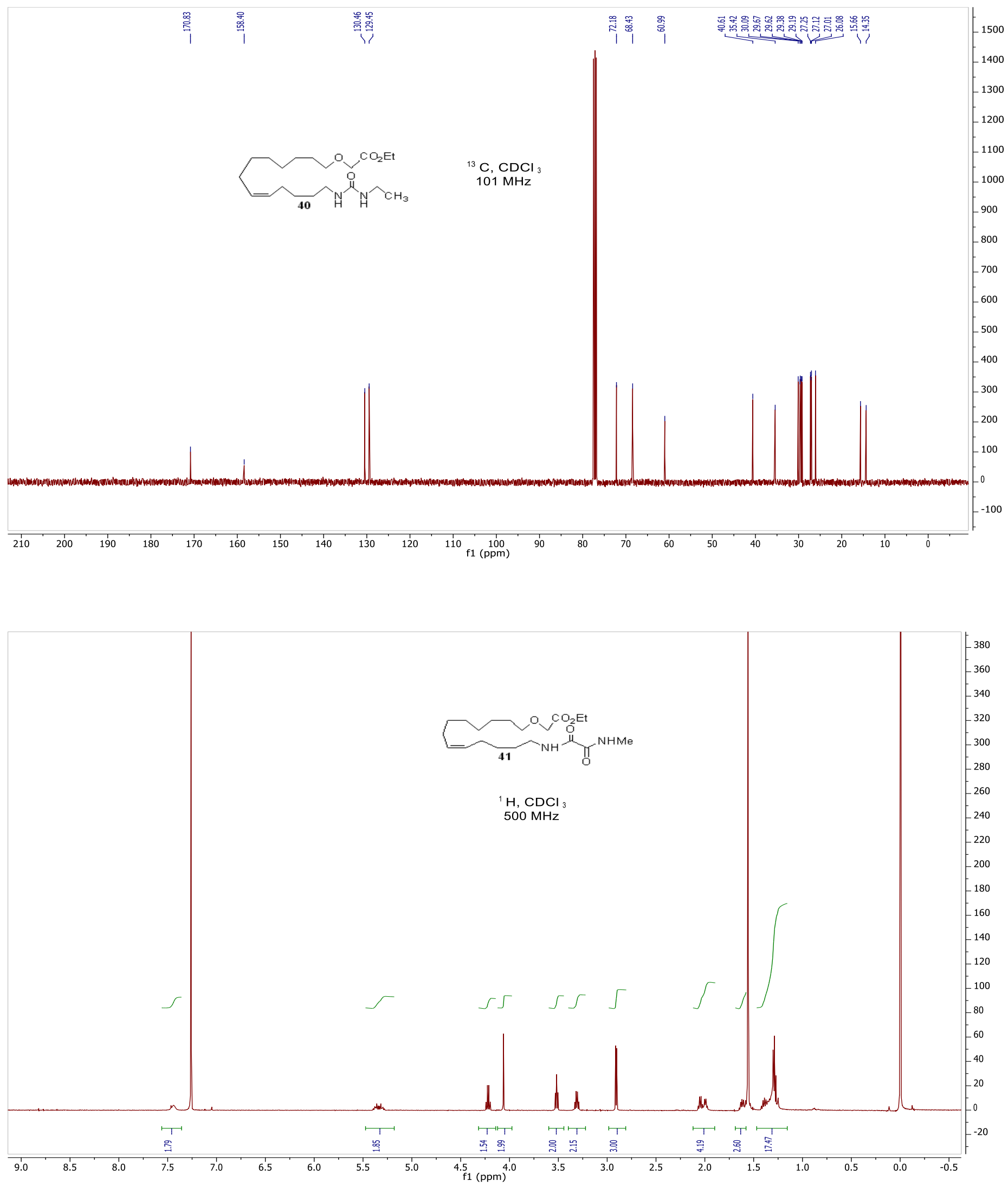

S42 

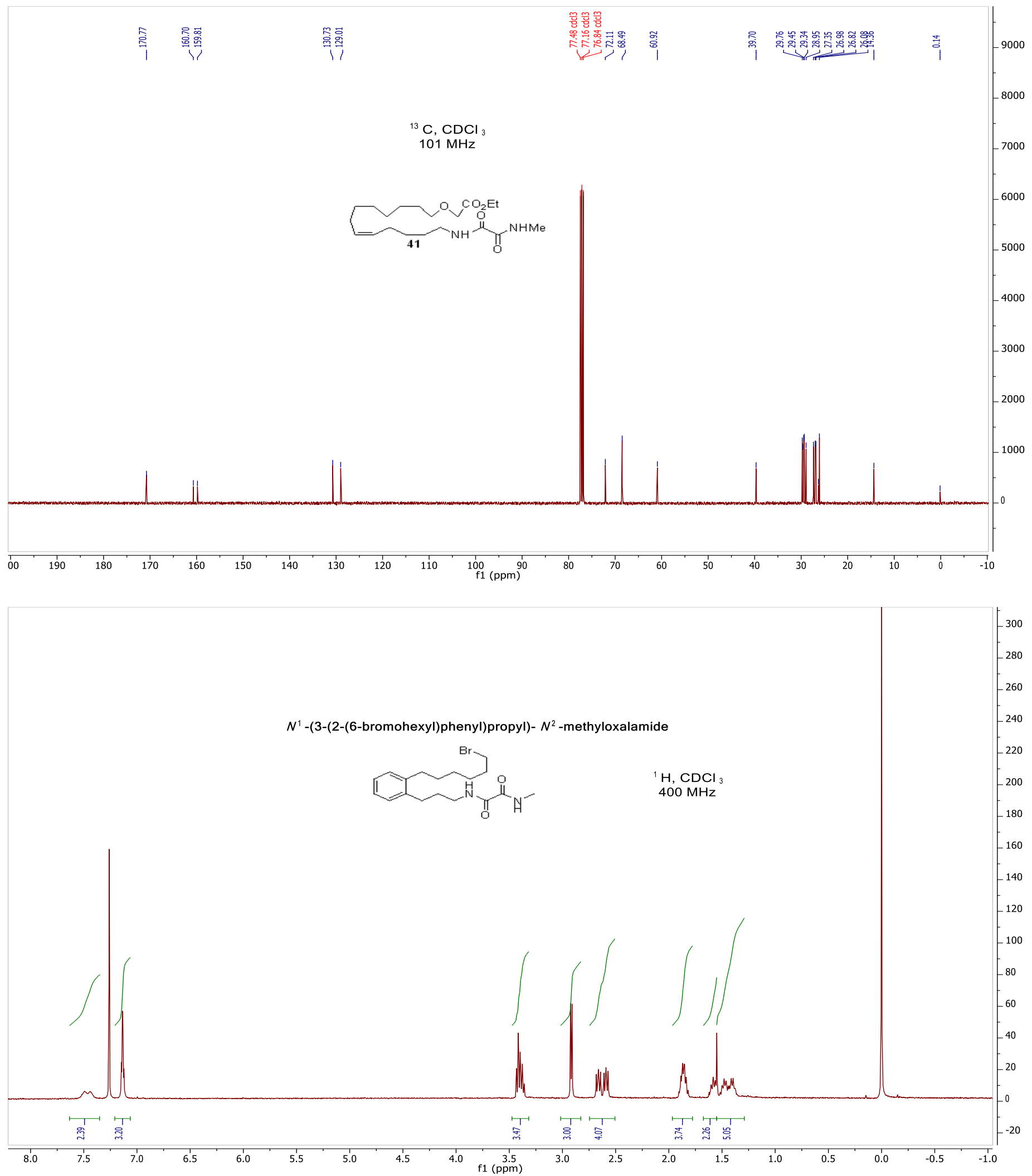


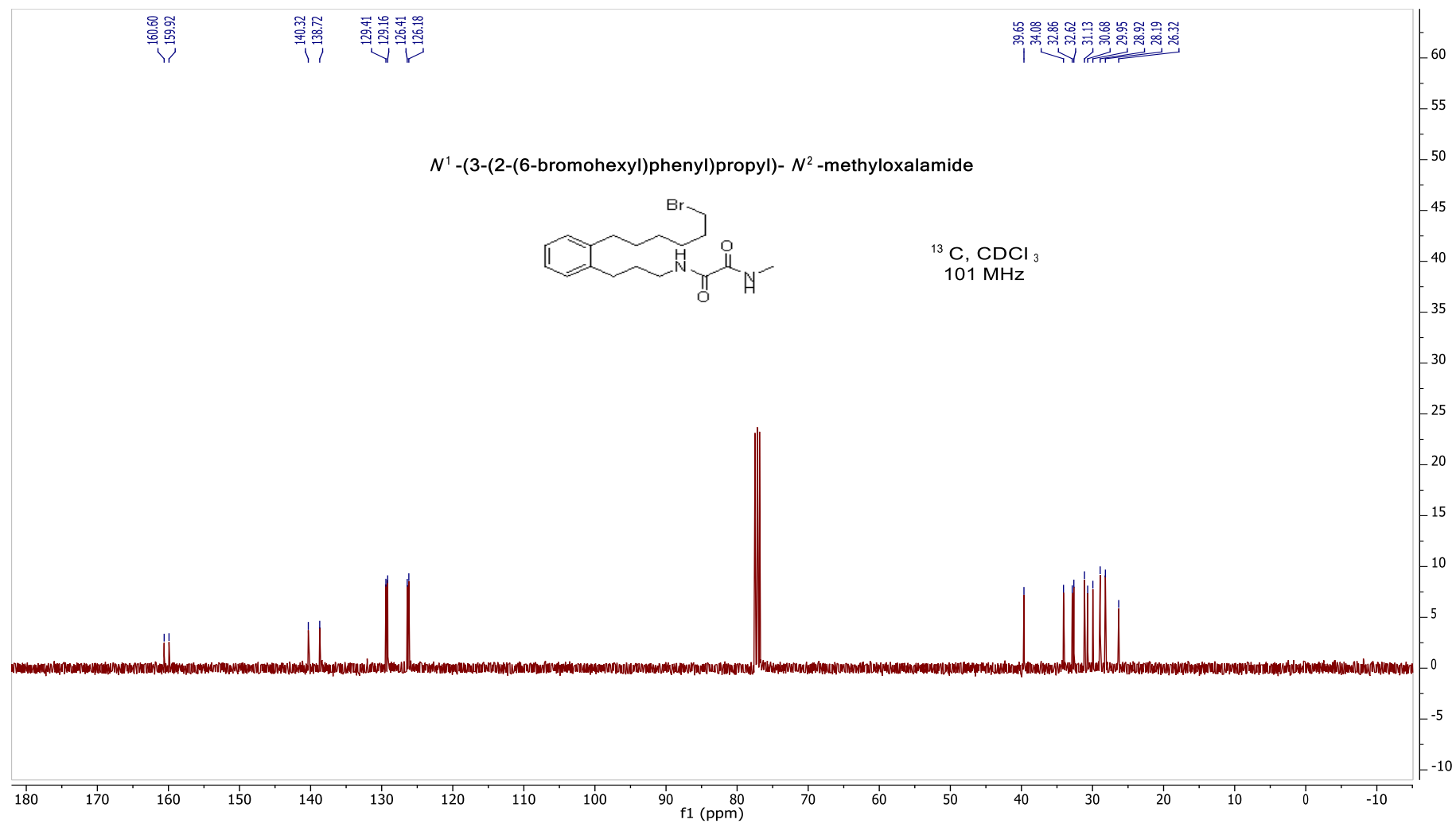

$N^{1}$-(4-(2-(9-bromononyl)phenyl)butyl)- $N^{2}$-methyloxalamide

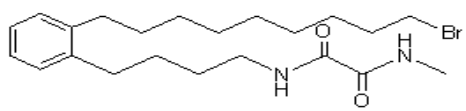

$\mathrm{H}, \mathrm{CDCl}_{3}$

$400 \mathrm{MHz}$

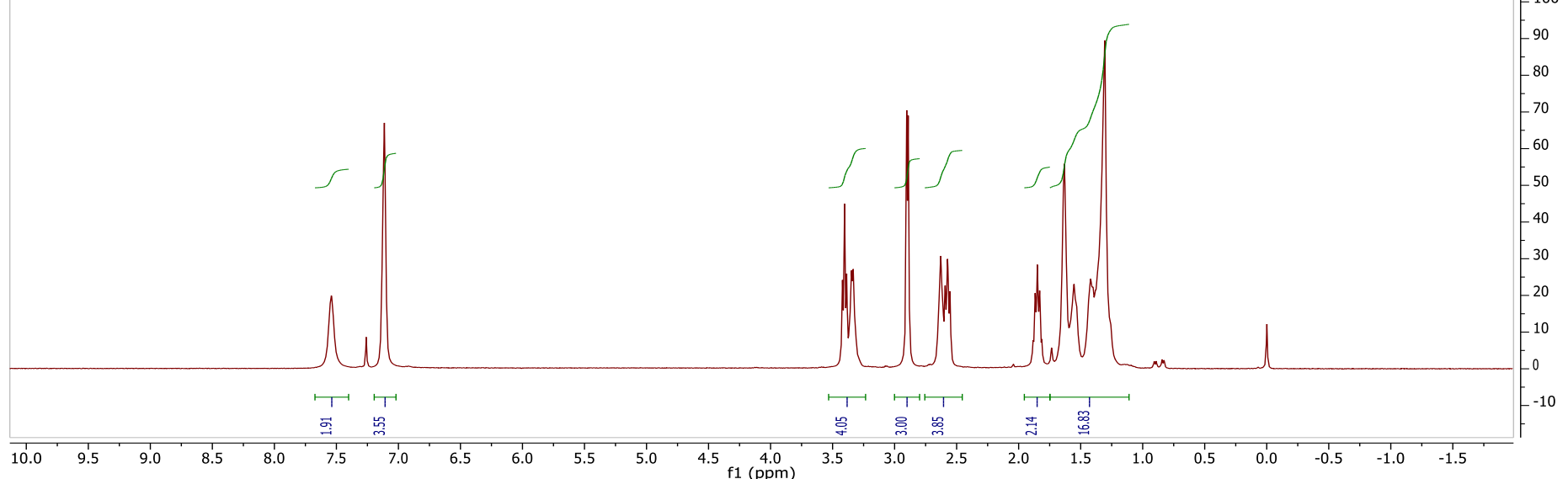




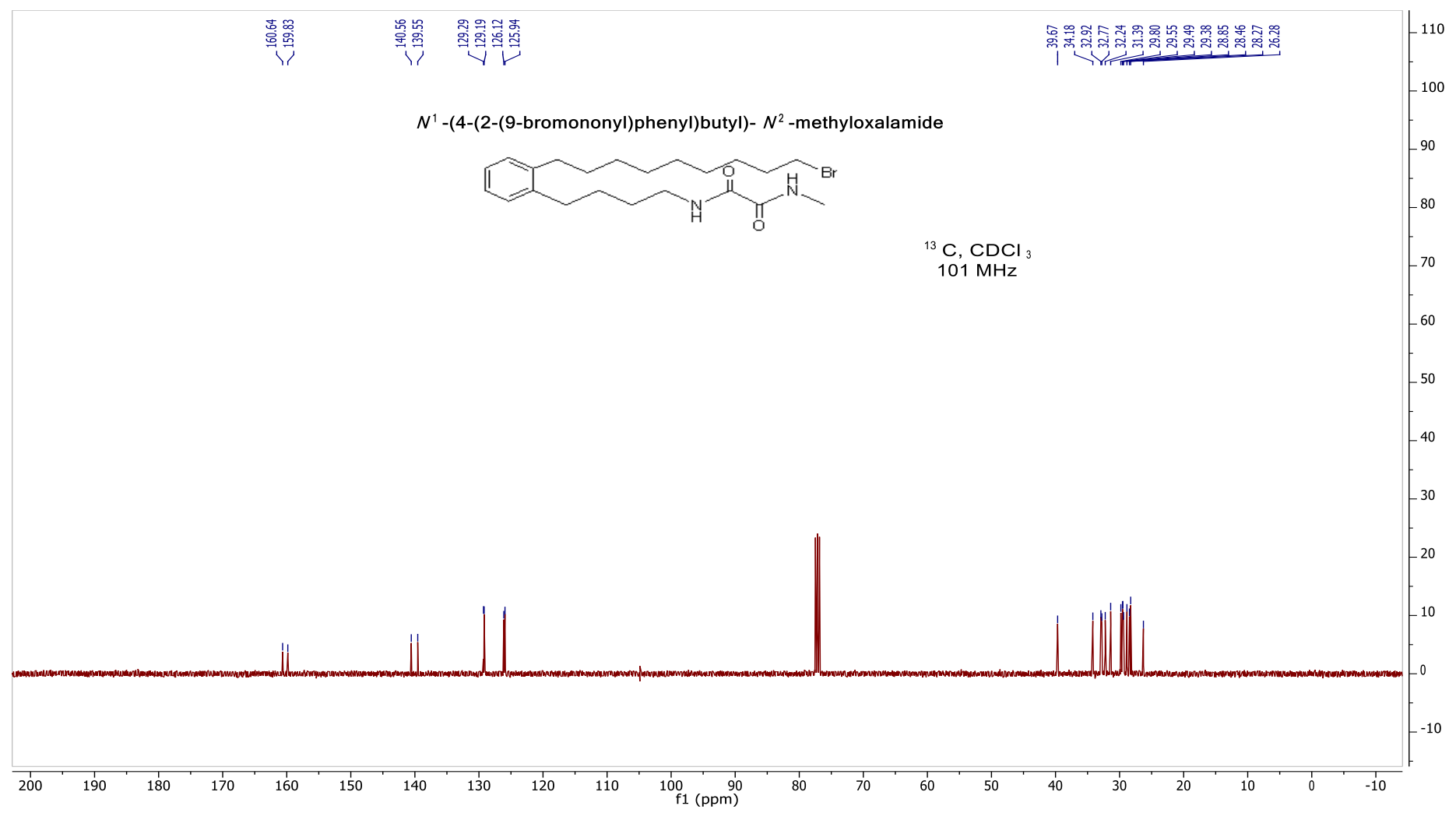

